Article

\title{
From Profit to Purpose: How Electric Utility Multinationals Visualize Systemic Change and Adaptation of Organizational Ethical Culture through Scenarios for 2040
}

\author{
Rodrigo W. Dal Borgo *(D) and Pedro M. Sasia \\ Centre for Applied Ethics, University of Deusto, 48007 Bilbao, Spain; peru.sasia@deusto.es \\ * Correspondence: rodrigo.dalborgo@deusto.es
}

\section{check for}

updates

Citation: Dal Borgo, R.W.; Sasia, P.M. From Profit to Purpose: How Electric Utility Multinationals Visualize Systemic Change and Adaptation of Organizational Ethical Culture through Scenarios for 2040. Sustainability 2021, 13, 12045. https://doi.org/10.3390/su132112045

\section{Academic Editors: Mónica}

Gómez-Suárez, Victoria Labajo and Donato Morea

Received: 15 September 2021

Accepted: 28 October 2021

Published: 31 October 2021

Publisher's Note: MDPI stays neutral with regard to jurisdictional claims in published maps and institutional affiliations.

Copyright: (c) 2021 by the authors. Licensee MDPI, Basel, Switzerland. This article is an open access article distributed under the terms and conditions of the Creative Commons Attribution (CC BY) license (https:// creativecommons.org/licenses/by/ $4.0 /)$.

\begin{abstract}
This article explores how top executives from two electric utility multinationals visualize systemic change and adaptation of their ethical cultures in the future. Allaire and Firsirotu's framework for organizational culture was incorporated with scenario planning which focused on the influence that the contextual environment exerts on building an organizational ethical culture. The study relied on a holistic and a systems thinking approach to cluster and evaluate six key themes perceived to lead to disruptions in ethical culture. Consequently arriving at the aim to conceive four possible scenarios for 2040 on the future of organizational dynamics and ethical culture in the private electric utility sector. The attributions of relevance for organizational ethical culture and the interrelationships among six key themes demonstrated the greater significance of two themes: From profit to purpose and Environment and Sustainability. As the main driving forces, these two themes guided the development of the scenarios and provided further insights into the flow of power relations, agency, and leverage points for an organizational ethical system.
\end{abstract}

Keywords: organizational ethical culture; business ethics; scenario planning; systems thinking; pragmatism; purpose over profit; sustainability; energy transition; electric utility multinationals; new business models

\section{Introduction}

There are ongoing discussions concerning the transformation that companies may need to undergo in order to meet the needs of its constituents by placing greater value on purpose over profit [1-4]. Public distrust, loss of legitimacy and damaged reputations are among the reasons given for this movement for change away from a profit only oriented model to one that society calls for. On this specific issue, Piketty [5] has already argued against the concentration of wealth by the owners of capital, which consequently exacerbates inequality. Some multinationals concentrate wealth with the ultimate purpose, being to maximize profit solely to gratify shareholders. These actions by corporations contribute to corroborate Piketty's thesis on the correlation of long-term and persistent inequality creating social injustice and fomenting civil unrest. Eeckhout [3] argues, "we tend to accept that when firms do well, the economy does well. Competing firms that make profit create jobs and work benefits. Alas, currently dominant firms exert market power and do the opposite" (p. 75). Excessive market power is in many cases in detriment of social responsibility and contradicts the conceptions of what should constitute an ethical culture in organizations. Recently there were attempts made by CEOs of major corporations to change their profit-centered rhetoric to a purpose-centered rhetoric, as the letter from Larry Fink of BlackRock struck a chord and generated some momentum in the corporate environment and in the media. From a social and ethical perspective, companies are expected to realize that profits and even the longer-term survival of their corporations depend on cultural transformation and diagnosis of disruptions that impact and shape their ethical cultures [6]. However, it remains to be seen if what they say and do is spin or 
if they will make substantive changes to serve a social purpose. Here then, our concern is electric sector multinationals and their commitment to a fair and just energy transition guided by purpose. For this study, understanding the contextual environment is crucial for companies to be able to map out and diagnose external disruptions in ethical culture and the processes by which these disruptions will shape their responses to corporate purpose and to both ethical and unethical behavior. The scenario planning approach encourages companies to distinguish their immediate actors (transactional environment), with whom they have direct contact, from macro driving forces (contextual environment), over which the company has no control [7].

Tone at the top which is usually framed within a company's stated purpose should be recurrently revised. For this study, the dialogue that was established with top executives in two multinationals emphasizes the future role of leadership with increasing responsibility for moral agency and voices their concerns about rapid changes in the contextual environment. Past studies have demonstrated and discussed the challenges encountered when attempting to apply qualitative multilevel analyses to organizational ethical culture [8-10]. Scenario planning, a strategic foresight tool, is proposed as a valid methodology to fill this gap by virtue of its iterative and inquiry driven contextual and transactional analysis [11]. The IPCC [12] in this regard emphasizes the use of future scenarios "to explore conditions enabling goal-oriented futures while recognizing the significance of ethical considerations, the principle of equity, and societal transformation needed" (p. 52). Thus, this empirical study builds on different phases of past research $[6,13]$ with two electric utility multinationals, hereinafter referred to as EUMa and EUMb. Based on six key themes, this article explores how top executives from the electric utility sector visualize systemic change and adaptation of their ethical cultures through scenarios for 2040. The first phase focused on futures thinking dialogue interviews with sixteen executives from EUMa in Europe and in its South American subsidiary. During this first phase executives reflected on the future development of their company and industry and the impact that these developments would trigger on their organizational culture and more specifically on the ethical dimension of their culture i.e., ethical culture. From this analysis, six key themes were diagnosed as potential disruptors to ethical culture in the electric sector: From profit to purpose, Cultural consistency, The role of leadership, Regulation and relationship with public institutions, Digital and technological advances, and Environment and Sustainability [6]. A subsequent phase was conducted in South America with six interviews at EUMa and seven interviews at EUMb where executives validated the themes, reflected on their positive and negative effects on ethical culture, and also identified weak signals that over time could amplify and cause disruption $[13,14]$. The final purpose of this phase was to elicit from the executives a systemic reflection on the causal relationships found among the themes. With this research, we confirmed the relevance of all six themes for organizational culture and identified a strong interconnection among them. These themes were above all transversally dependent upon From profit to purpose and Environment and Sustainability and shaped the narratives of the four future scenarios. None of the six themes work alone and many factors for an ethical business model transition may depend on issues external to the organization, such as new and old public policies and regulations. Hence, the aim of this article is to reassess the previous findings through an adapted framework and create four possible and plausible scenarios for 2040 on the future of organizational dynamics and ethical culture in the private electric utility sector. Thereby, we address the implications of the scenarios for both companies and their strategies for sustainability, i.e., Sustainable Development Goals (SDGs), and ethical positioning. The process through which we arrived at the scenarios can transcend to other multinationals of the electric sector as well as to multinationals of other industries.

Here, this research wishes to contribute to the studies of organizational ethical culture by mapping possible disruptions highlighted by the executives and which, subsequently, led to diverse narratives for the future. With the analysis of the themes and development of the future scenarios, this research further wishes to contribute to understanding the 
processes of business model transitions that come to value purpose over profit within organizational dynamics, and that encompass ethical organizational means by which to tackle contextual and transactional challenges in order to pinpoint responsible approaches to change.

The rest of this article is organized as follows. Section 2 defines ethical culture as a complex system and relies on the theoretical background of organizational culture and ethical culture studies, systems theory, and pragmatism. Section 3 introduces the framework used for the analysis and the scenario planning methodology. Section 4 presents the results and discusses the process relating to all six components in the framework, the implications for ethical culture, and four possible future scenarios. Finally, in Section 5, we offer conclusions, indicate the implications of the scenarios and suggest directions for future research.

\section{Ethical Culture as a Complex System}

\subsection{Organizational Ethical Culture}

Schein [15] explains that there are roots of complexity leading to a definition of organizational culture as the "concept of organization itself is ambiguous". In order to confront this ambiguity, Schein [15] recommends an understanding of the history and the dynamics that lead to the formation of a culture, where its strength should be "empirically determined". That is, there are different levels of culture that help create evidence and determine if a group or organization with cognitive abilities is prepared to learn, evolve and adjust itself according to the "external environment and its problems of internal integration". Sasia [16] adds that the moral development of an organization depends upon untangling the webs of significance to which culture belongs [17] such as attempting to make sense of its fundamental elements (norms, symbols, conduct and structure), but most importantly to 'permanent elements' such as the type of rationality that inspires an organization and determines its ethical positioning. Schein [15], and Allaire and Firsirotu [18] had already illustrated organizational culture as a system, which contains subsystems and includes elements that are in complex relationships. As with systems and subsystems, organizational culture has subcultures. Within the subsystems of culture there is an ethical dimension called organizational ethical culture, which determines the aptitude of an organization to ensure moral reasoning and to build appropriate structures for the ethical development of the organization and its employees vis-à-vis social legitimacy, fairness, justice, responsibility and human rights. Treviño et al. [19] defined ethical culture "as a subset of organizational culture, representing a multidimensional interplay among various formal and informal systems of behavioral control that are capable of promoting either ethical or unethical behavior" (p. 451). The authors explain that the formal or explicit systems are constituted of policies, leadership authority, structures, rewards systems and training programs, while the informal or implicit systems refer to behaviors of employees and peers in relation to ethical norms. Therefore, ethical culture is a complex system which emphasizes "observable manifestations of culture such as structures, systems and organizational practices" [19] (p. 451), which influences ethical behavior, "cognitive processes" [20], and "provides guidance to employee ethical decision-making" [21]. This notion that ethical culture influences behavior determines that there are causal relationships that constitute an ethical culture. More so, if we consider that ethical culture is also a multidimensional construct of virtues [22,23], which an organization is, required to evaluate in order to put their subjective values into practice. Elements, factors, dimensions and characteristics either external or internal to the organization are interconnected and highlight the various types of relationships that may occur. These interconnections and relationships can demonstrate whether an ethical culture or ethical system is in a reinforcing or balanced feedback loop [24]: (1) Reinforcing feedback loop towards an ethical culture or reinforcing towards an unethical culture. (2) Balanced feedback loop for a stable and strong ethical culture or an ethical culture that can be resistant to change and is not current with evolving social needs. 
Werhane [25] explains that a healthcare system and its subsystems are open, dynamic and revisable. The same logic is attributable to any organizational culture and its subcultures (viewed as systems) and to its ethical system, a subset of culture. An ethical system in organizations is not a closed system, neither is it static. It evolves and adapts or at least it should. As the contextual environment is in constant shift, organizations need to be aligned to the values and the evolving ethos of society in order to focus on the well-being and interests of those who are affected by their actions. This is especially true, if we are to consider that culture matters and motivates expected actions of an organization when confronted with ethical challenges [26].

\subsection{Systems Thinking and Pragmatism}

We invite the reader to embrace the theoretical conception that organizational ethical culture is a socioecological complex adaptive system. A system with interactions of complicated structures, patterns and composed of characteristics of aggregation, nonlinearity, diversity and flows [27]. Hence, similar to biological interactions, "the ecological nature of an organizational ethical system focuses on the interconnections and interdependencies between the organization and the many components that influence its functioning, be they external (environment, technology, government ... ) or internal (employees, clients, competitors)" [13] (p. 82). We remind the reader that ethical system and ethical culture are used interchangeably throughout the article.

Bertalanffy [28] introduced the scientific concept of "wholeness" with general system theory (p. 37). The author suggests that a 'unitary conception of the world' and science is founded on the possibility of amplifying perspectives through the complex relationships and interactions among various organizational levels, disciplinary fields and relationships. The progress in engineering, most specifically power engineering, and the outbreak of World War II, with the use of cybernetic feedback, were the main driving forces for the development of a systems approach, due to the evolving complexity of interactions that the rise of technology stimulated in the field [28,29]. Additionally, systems theory and thinking built its reputation in organization and management studies [30-33], which led to its philosophical, social, environmental, political and ethical evolutionary importance [24,34,35]. Thus, systems thinking has been acknowledged as a relevant theoretical, practical and operational science of business ethics [25,36-41].

Werhane [39] argues, for example, that with a multiple perspective approach, ethical issues can be examined, first, from a sociological point of view and, second, by establishing boundaries. With the latter, a systemic overview can be beneficial for organizations seeking to assess and to strengthen their ethical cultures by identifying boundaries to their moral development i.e., as they are either influenced externally by regulatory barriers, political instability or evolving societal values, or internally by moral agency and the future role of leadership. From a sociological point of view, we can review the effect of an organization's purpose and goals for the functioning of its ethical structure, interrelationships and ethical rationality.

Organizations are purposeful systems [36,37]. However, the purposes of these systems first need to be articulated if they are to guide an organization for the common good of society and to optimize 'collective value' [2]. On the tenets of pragmatism, Ackoff [37] reminds us that American pragmatism considers meaning, as a near equivalent to purpose, to be valuable when we attempt to understand where it leads us in practice. Organizations should ask themselves where their purpose will lead them, whom they will benefit and to whom they might engender harm. The ultimate meaning of an organization's purpose and the ethical challenges that an organization might face are posed through iterative inquiry, which can generate the necessary knowledge for responsible practices and actions. Dewey [42] argues that "inquiry is a continuing process". The settlement of beliefs is a progressive matter where further inquiry will only help to define knowledge. Moreover, American pragmatism is "a philosophy in which diagrammatic representations 
of relationships per se are seen to constitute an important part of scientific inquiry" [43] (p. 479).

\section{Framework and Method}

\subsection{Framework: Adapted from Allaire and Firsirotu (1984)}

Allaire and Firsirotu [18] in 1984 proposed an integrated conceptualization of organizational culture in which the authors address the issues of social legitimacy and determinants of change and adaptation in organizations. In order to arrive at their framework, the authors aligned the analysis and classification of studies in cultural anthropology with literature in the fields of management and organization studies. Their conceptual framework has provided the foundation and inspiration for this article due to its holistic conceptualization of organizational culture and due to the relevance it gives to the influence culture receives from the contextual environment, and most specifically, to the understanding of corporate cultural legitimacy. For the purposes of this study, which applies the scenario planning methodology with a systems thinking approach, Figure 1 is an adapted version of Allaire and Firsirotu's framework. Descriptions in each component of the framework lead us towards the creation of possible emerging future systems of ethical culture and their dynamics according to a systemic analysis of the different driving forces, trends, assumptions and characteristics. The steps and components of the framework are:

(1) History: an overview of interviewees' historical perspective of the sector and of the organizations is introduced. This overview also reveals historical corporate and sector transformations.

(2) PESTLE: introduces the-political, environmental, social, technological, legal and economic - analysis of the sector. This analysis considers the driving forces that were perceived by interviewees to influence corporate culture and transitions to new business models.

(3) Business Idea: according to van der Heijden [44] "the Business Idea is the organization's mental model of the forces behind its current and future success" (p. 63). It is illustrated as a reinforcing feedback loop, which can amplify a healthy culture or reinforce tendencies of a toxic culture. While van der Heijden conflates the articulation of the Business Idea with an organization's success and profitable growth, this article articulates the Business Idea in terms of managing success and development of an ethical culture. The articulated business idea was reassessed in this study with the scenarios in order to identify leverage points and improve its ethical coherency e.g., reviewing which Sustainable Development Goals are addressed in each of the scenarios and which ones need to be reconsidered.

(4) Cultural System: refers to interviewees' underlying assumptions and beliefs of the organization's culture, beyond codes of ethics and explicit corporate values. This component also considers corporate reports and ethnographic research conducted during two residencies at EUMa.

(5) Socio-structural System: refers to structures, strategies, policies and processes that are developed by the organizations to build or maintain an ethical culture at EUMa and $\mathrm{EUMb}$. Here there is an emphasis on evidence from EUMa where the author of this article had two corporate residencies, and from a seminar presentation by an executive of EUMa at an ethics forum.

(6) Organizational Output: combines findings from other components of the framework (PESTLE, History, Business Idea, Cultural System, Socio-structural System) to introduce six key themes as possible disruptors of ethical culture. A preliminary causal loop diagram (CLD), which demonstrates interconnections of two key themes-From profit to purpose and Environment and Sustainability — and their top terms, are presented. Subsequently, four future scenarios to the year 2040 were built based on the reflections of interviewees on the relevance and influence of the key themes for organizational ethical culture. 


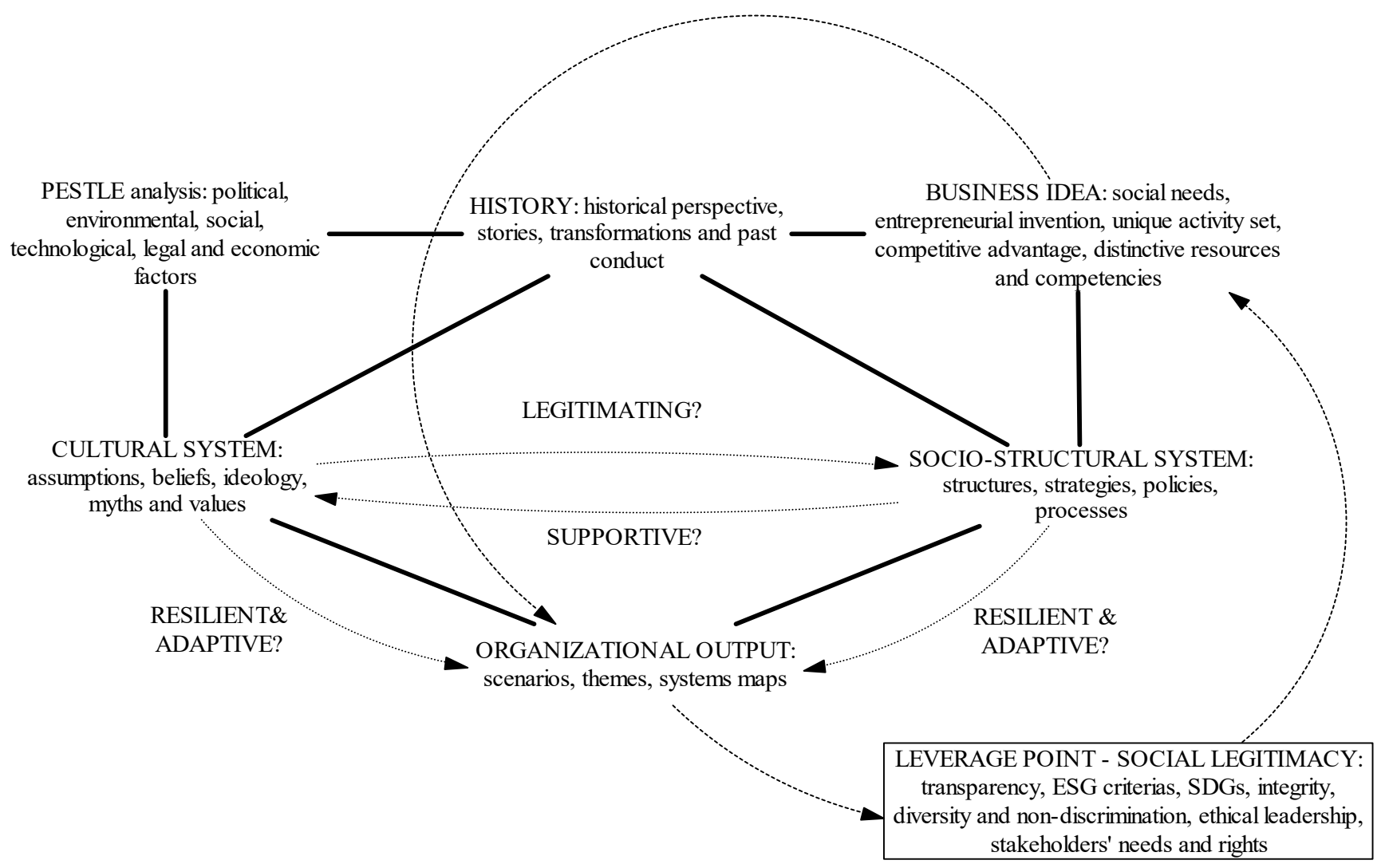

Figure 1. Framework used for analysis adapted from Allaire and Firsirotu (1984).

\subsection{Methodology: Scenario Planning}

Scenario planning is a methodology to envision various possible and plausible futures in the format of scenarios or narratives. Organizations have applied scenario planning to deal with turbulent and uncertain contextual environments and to be better prepared strategically for futures that might unfold. It has been a useful tool to reframe strategy [45], support decision-makers [46], maximize innovation capacity [47] and support policy making [48]. Furthermore, this foresight methodology also advocates for an eminently human and social perspective [49], which has the potential to transcend to the corporate setting as a diagnostic tool for ethical culture [6] and to assess an organization's ethical culture [13].

Inspired by an inductive method of intuitive logics [50] and with an adaptive scenariobased planning approach [44], by which our reality should see ethical culture as a complex adaptive system, the scenarios are informed by causality and interconnections through the framework (Figure 1). Here is where systems thinking has played an important role in making sense of the complexity of ethical culture and building future possibilities. The art and science of scenario planning is realized by its usefulness in making sense of a system as a whole, as opposed to separate isolated parts thereof [44,51-53]. The importance here is to perceive those parts as interconnected and interdependent in order to visualize possible future scenarios and to ensure that they are plausible. Therefore, this study embraces the contributions that complexity science has for futures studies [54] and the importance of socio-ecology to scenario building [55].

\subsection{Data Collection and Analysis}

The following section and subsections are depictions of each of the components encountered in the framework (see Figure 1) which are first retrieved from the interviews conducted at EUMa and EUMb, second, by ethnographic research conducted at EUMa during two residencies in the organization and third, with the support of literature and reports, either corporate reports or from international organizations. There were two 
phases of the research which included a total of 29 interviews with top executives from two private electric utilities. The first phase interviewed 16 executives of EUMa in the European headquarters and in a South American subsidiary (see Table 1) by which six key themes were identified by the executives to potentially disrupt and influence ethical culture (see [6]). A subsequent phase of the research was conducted in South American subsidiaries of two European multinationals (EUMa and EUMb). In three South American cities, 13 more interviews were conducted with executives (see Table 2). This phase aimed to validate the relevance of the previously identified six key themes for ethical culture, their interdependencies and their interrelationships. For this final phase, each executive was interviewed with reference to a specific theme related to their expertise and knowledge with the theme e.g., the theme Environment and Sustainability was conducted with the heads of sustainability in the organizations or with executives who had dedicated work to this field. All interviews were carefully regulated, transcribed and coded using a qualitative analysis software (Table 3). The following section goes over each component of the framework, which leads us to the organizational output with the six key themes, two systems maps and four future scenarios.

Table 1. First Phase Interviewees at EUMa.

\begin{tabular}{cc}
\hline European Headquarters & South American Subsidiary \\
\hline Head of Energy Planning & Head of Tax and Accounting \\
Head of Sustainability and Risk Management & General Counsel \\
Head of Innovation & Head of Regulation and Energy Planning \\
Head of Organizational Development & Head of Planning and Control \\
Head of Human Resources & Head of Internal Audit and Compliance \\
Head of Stakeholder Management & Director/President of Partner Company \\
Executive Board & Head of Construction and Operations \\
General Director & Head of Distribution \\
\hline
\end{tabular}

Table 2. Second Phase Interviewees in South America (EUMa and EUMb) and Associated Themes.

\begin{tabular}{|c|c|c|c|}
\hline EUMa Interviewees & Theme & EUMb Interviewees & Theme \\
\hline $\begin{array}{c}\text { Regulatory Executive } \\
\text { Manager }\end{array}$ & $\begin{array}{l}\text { Regulation and } \\
\text { relationship with } \\
\text { public institutions }\end{array}$ & $\begin{array}{l}\text { Head of Strategy and } \\
\text { Regulation Officer }\end{array}$ & $\begin{array}{l}\text { Regulation and } \\
\text { relationship with } \\
\text { public institutions }\end{array}$ \\
\hline $\begin{array}{c}\text { Sustainability } \\
\text { Executive Manager }\end{array}$ & $\begin{array}{l}\text { Environment and } \\
\text { Sustainability }\end{array}$ & $\begin{array}{l}\text { Head Administrative } \\
\text { Officer, with } \\
\text { emphasis in CSR and } \\
\text { Sustainability }\end{array}$ & $\begin{array}{l}\text { Environment and } \\
\text { Sustainability }\end{array}$ \\
\hline $\begin{array}{c}\text { Head of Mergers and } \\
\text { Acquisitions }\end{array}$ & $\begin{array}{l}\text { From profit to } \\
\text { purpose }\end{array}$ & $\begin{array}{l}\text { Deputy Ethics and } \\
\text { Compliance Officer }\end{array}$ & $\begin{array}{l}\text { From profit to } \\
\text { purpose }\end{array}$ \\
\hline $\begin{array}{l}\text { Vice President of } \\
\text { Generation }\end{array}$ & The role of leadership & General Counsel & The role of leadership \\
\hline $\begin{array}{l}\text { Vice President: } \\
\text { Strategy and Business } \\
\text { Development }\end{array}$ & $\begin{array}{c}\text { Digitalization and } \\
\text { technological } \\
\text { advances }\end{array}$ & $\begin{array}{l}\text { Head of Commercial } \\
\text { and Innovation }\end{array}$ & $\begin{array}{l}\text { Digital and } \\
\text { technological } \\
\text { advances }\end{array}$ \\
\hline \multirow[t]{2}{*}{$\begin{array}{c}\text { Head of } \\
\text { Transformation }\end{array}$} & Cultural consistency & $\begin{array}{l}\text { Head of People and } \\
\text { Culture }\end{array}$ & Cultural consistency \\
\hline & & $\begin{array}{l}\text { Head of Strategy, } \\
\text { Communications } \\
\text { and CSR }\end{array}$ & $\begin{array}{l}\text { From profit to } \\
\text { purpose }\end{array}$ \\
\hline
\end{tabular}


Table 3. Description of Electric Utilities and Regulation of Interviews.

\begin{tabular}{cc}
\hline \multicolumn{1}{c}{ Electric Utility Multinationals } \\
\hline Sector & Electric Power/Gas \\
Market & European/Global \\
Number of Interviews & 29 \\
Average Interview Length & 71 min \\
Average Transcript Length & 6568 words \\
\hline
\end{tabular}

\section{Results and Discussion}

This section covers the framework introduced in Section 3 and leads us to the development of future scenarios. The interviews for the study took place over the course of a European Commission doctoral fellowship (2016-2020) to research the topic-promoting ethical culture in multinational companies. The research was accomplished before the COVID-19 pandemic and the exacerbated climate events that have accompanied it. Many of the concerns expressed by the executives during the time of the interviews are largely the same as the concerns and disruptions which we are experiencing in the present e.g., water crises (droughts), climate change, high energy prices for consumers, $\mathrm{CO}_{2}$ pricing, transition to tech business models, focus on renewable energy, upskilling workers etc. The COVID-19 pandemic exposed these concerns to media attention and thus the attention of a wider audience.

\subsection{History-Historical Perspective Overview}

The culture of an organization, considering the reach and size of multinationals such as EUMa and EUMb, is perceived to develop from a collective reasoning and this collective reasoning is influenced by foundational elements from their past. Therefore, this analysis of the historical perspective identified that the shared internal knowledge and organizational culture of these specific organizations of the electric sector were dependent upon how well the organizations read their contextual environments and were capable of adapting and changing accordingly, and thus contribute to the well-being of society. In Europe, for example, there was a clear belief that providing energy to society is a service of public interest, by which a number of obligations and attitudes define a utility's actions. The idea of being a public service raised awareness of the need for values such as transparency and honesty, reflected in how much energy is consumed and the true measurement of this in homes, such that consumers have greater control over their own consumption and cost. These values are ever more relevant because electricity is a service upon which the welfare, and the livelihoods of populations depend. Looking back, from Thomas Edison's light bulb, which shaped modern society, to Charles Proteus Steinmetz contributions to the field of electrical engineering, the growing dependency on the electric sector proliferated as there were further technological advances accompanied by exponential socioeconomic growth. Society's dependency is conditioned by utilities that act throughout the entire value chain of generation, distribution and transmission, which confronts the concept of public service and the balance between fair corporate profit and its crucial corporate purpose as a social service.

Ultimately, some of the main drivers of cultural change are connected to the way organizations and their employees position themselves in respect of their setting and how these organizations insert themselves into given societies. Therefore, according to the executives in the two electric utilities, which are globally present and over time have acquired several other companies, there is a need to recognize the complexity of building a 'sane' organizational culture and the challenges faced in doing so. Increasingly, every geography and business unit has its own particularities and identities.

In South America, the executives expressed the belief that their European counterparts (headquarters) respected the organizational cultures of the acquired local companies because the existing management teams and core employees were retained. For strategic transitions in South America, they had sought to maintain cultural traditions and 
dynamics whilst recognizing the need to adapt to a new business environment. Additionally, both multinationals had undergone similar transformations i.e., from government entity in Europe to privatization, and to expanding their worldwide market and becoming international players with South American subsidiaries. External challenges were also encountered with respect to past government decisions and provisionary measures, which in the interviewees' perceptions delayed progress in the South American sector and in innovation and development to this day. Government regulations oblige companies to adapt to new sets of rules, which in some cases may result in losses to income. To an even greater extent, the executives considered that the implementation of new regulations disregarded the fact that the electric sector is a value chain. Thus, the capacity of financial resilience to changes in the regulatory system also depends on exogenous environmental factors such as water crises. In this South American example, the companies and other actors of the electric sector, resorted to legal action in order to be exempted from bearing the burden of the costs resulting from what they understood to be a poor regulatory framework, further aggravated by a drought, which resulted in a water crisis. Over the years, this has transformed the companies' strategic positioning in the sector to refocus management attention and efforts to devote more resources to building strong in-house legal departments, which in turn instigated a culture of litigation. Nevertheless, EUMa, in South America, took this opportunity to diagnose the issues affecting the sector imposed by the barriers and impediments in the regulatory framework. EUMa dedicated internal resources to participate in public hearings and propose options and socially relevant initiatives to government, which should spur government to enable and simplify mechanisms for the development of renewable energy. This demonstrates that the relationship of the structuring of "corporate governance practices on performance" and "country rules" [56] is a case in point on how regulatory bodies may influence the tone at the top of an organization and its cultural characteristics and ethical positioning.

\subsection{PESTLE Analysis-Setting the Contextual Scene}

This section covers the PESTLE analysis component of the framework. The objective of identifying and depicting a picture of macro and micro driving forces is supported by the logic of distinguishing the current situation of the electric sector and the externalities that will influence its evolution and may impose change in the organization's ethical culture. The driving forces are categorized by a PESTLE-political, environmental, social, technological, legal, and economic - analysis with a description of each PESTLE setting.

\subsubsection{Political Setting}

Political division and instability pose a risk for the electric sector. However, according to interviewees from EUMa and EUMb, aspired values guide them to implement an infrastructure and vision in which renewable energy such as solar and wind prevail whilst substituting coal. The political risk itself is actually related to extreme events that may occur with a coup d'état, a World War or government takeover of private electric companies. Yet, the actions of individual climate change skeptics have little to no effect on an environmental agenda set by the businesses [57]. The greater purpose of decarbonization and other climate actions may actually demonstrate the commitment and cohesion of businesses to assume corporate political responsibility [58].

Furthermore, one of the greatest challenges will be to adopt a model, which will guarantee more stability to the electric sector in relation to lower costs (for the sector and for consumers), transparency, and economic and socio-environmental sustainability. This is a long-term path to achievement, which needs imminent action and political support to avoid wasted time [59]. With political and economic stability, the electric sector will benefit from investments in order to continue with a renewable energy transition. The purpose for which the electric sector pursues the decarbonization of its markets also depends on government participation. However, the executives argued that the technological development for renewable energy has become more competitive than fossil fuel technology 
and has facilitated climate action even when there is a lack of political support. Arguably, two driving forces for the electric sector are technological advances and a coherent political framework for the development of energy policies. Therefore, educating politicians is seen by the executives as an option by which to reach a more stable and transparent regulatory system, since climate change may be perceived by some political actors as a long-term issue.

Finally, this takes us back to a growing demand from society on the influence that private companies should exert in the political realm to ensure responsible actions, or as interviewees expressed, to ensure a coherent political framework for the development of energy policies. This is a change in an organization's ethical culture towards an agenda for multinational activism that would demonstrate commitment to a continued effort to promote equality, justice and fairness despite a political ideology differing from that of government leadership. Noticeably, a code of conduct and corporate training on the meaning of multinational activism, expressing its reach and limitations, should be developed and disseminated throughout any influential organization.

\subsubsection{Environmental Setting}

For the executives of EUMa and EUMb on both continents, Europe and South America, there was a deep concern about droughts and water shortages as underlying contextual factors for future crises in the sector. With extreme climate conditions, they viewed this to be an unpredictable alteration, which places countries that are overly dependent on hydropower to the test as to whether they would be able to transition among different renewable models during shortages. The electric sector, therefore, would need to adapt itself to these climatic circumstances, particularly when the country has a strong hydraulic dependency.

The most controversial subject is the production of thermal energy based on oil and coal. One of the urgent strategic sustainability objectives of EUMa and EUMb is to decarbonize. However, there is a shared understanding by the executives that achieving $100 \%$ clean energy will be financially and politically challenging. Wind and solar energy have been evolving more rapidly over the years. Nevertheless, they are still intermittent energy sources, which at some point will need the support of low cost thermal energy power. Decentralization is based on the principle of divestment of the thermoelectric plants, especially coal-fired plants. Divestments allow the sector to shift its focus to renewable energy generation (solar, wind or hydroelectric). These are perceived to be the strategic foci of electric utility companies.

Undoubtedly, the electric sector is going through a transformation and the main catalyst for this transformation is climate change. One interviewee observed that the sector was responsible for $1 / 3$ of $\mathrm{CO}_{2}$ global emissions. If we were to specify only coal-fired electricity generation, the sector would have accounted for $30 \%$ of global $\mathrm{CO}_{2}$ emissions [60]. In 2020, two primary factors contributed to a $2 \%$ decrease in global $\mathrm{CO}_{2}$ emissions, the result of lower electricity demand due to the COVID-19 pandemic and an increase in wind and solar generation. Yet, the electric sector is far from an ideal transformation, as it has not fully undertaken the necessary actions to confront climate change, and with coal energy generation expected to pick up in 2021 [61]. This entails necessary measures of adaptation to climate change such as the European Union Adaptation Strategy and the European Green Deal. We may consider, on the other hand, that these adaptive measures need systemic commitment to actions. In practice, this has shown to be elusive and unattainable. IPCC [62] reports that "very few countries, regions, communities or businesses" are capable of adapting to the Paris Accord's ambitions without, for example, achieving SDGs in developing countries (p. 319).

Although there is still excessive dependency on fossil fuels, renewable energy will gain more terrain and thermal energy, such as coal and gas, will have their role diminished in supplying energy and producing electricity. This has been shown during the last ten years [63] with global electricity generation from coal decreasing and renewables on the rise. In addition, the lower cost of technologies has supported this trend. Finally, the executives 
understood that a robust global financial intermediation system would be necessary to confront the colossal investments to support the energy transition, which was seen to be beyond the structural, operational and financial capacities of some organizations.

Global warming has dire consequences for our environment. For this reason, the IPCC [64] states in its 5th Assessment report that there is a need for mitigation and adaptation efforts to confront climate change. Climate change will affect livelihoods in society as a whole, with greatest impact on the most vulnerable populations. Corporations and specifically, for the purposes of this article, electric utilities, need to adapt, change and build their ethical cultures around principles that will guarantee an equitable, fair and just energy transition. Already for decades, international organizations, such as UNESCO, have been working under consultative and collaborative frameworks to establish ethical principles for climate change adaptation and mitigation. UNESCO's World Commission on the Ethics of Scientific Knowledge and Technology (COMEST) has produced several reports for this awareness [65-68]. These are principles that electric utilities can incorporate into their decision-making processes, codes of conduct, values and corporate training for ethical awareness in processes that seek to accelerate a just and fair energy transition.

\subsubsection{Social Setting}

There is a question about the social role that energy plays and if companies in the sector are meeting the needs of society. In 2019, 770 million people had no access to electricity, which is a considerable decrease from 2018 when 860 million had no access and 940 million in 2016. Without access to modern energy, populations are affected by poor sanitation, the absence of clean water and precarious healthcare [69-71]. Not only does the electric sector have this vital social role to continue improving energy access to the world population, it also has to consider the means by which it is attempting to achieve this goal. The executives conveyed their convictions that companies will need to consider challenges regarding the increase in energy consumption without at the same time increasing greenhouse gas emissions, as well as the effects of climate change and the impact of displacing native populations to build hydroelectric dams and power plants. Energy transitions towards a low carbon economy require alternatives for workers who may lose their jobs and livelihoods due to overall deficient planning of job replacement and upskilling, e.g., coal miners. For this, an ethical culture in the electric sector should address social needs within sustainability standards from a climate action vantage point, but also from an economic point of view for affected populations. In order to enable a just energy transition and avoid a high occurrence of unethical behavior in the energy sector towards society [23] action plans are needed for energy workers and communities [72].

Aside from the importance of policymakers in providing a just transition, there are organizational opportunities to build a culture that upskills employees and future employees in order to qualify professionals for new organizational dynamics. This future preparedness for upcoming professionals requires focused efforts of new leadership to continue to guide the organizations towards sustainable goals and develop further the fulfillment of pressing social needs. Another aspect of upskilling takes into consideration automation and job loss. The new industrial revolution has placed challenges and targets to be reached by companies in order to avoid doomsday scenarios, in which robots are the cause of massive unemployment. A risk which is real if governments and companies do not target factors of structural change such as new skills, rapid ageing population, adapting social protections and unemployment caused by the COVID-19 pandemic [73-75]. On the other hand, with innovation, a recent study has shown an increase in employment in the renewable energy sector [76].

\subsubsection{Technological Setting}

Today the sector is shifting towards the needs of consumers as being autonomous energy producers (prosumers); therefore, this shift is trailed by decentralized solutions where we find new roles in the management of information, data processing and digitaliza- 
tion. According to the interviewees, this will cause a corporate cultural revolution on the relationship between electric companies and their clients. Consequently, the production of electricity in large centralized electric power plants and thermal power stations may soon be used strategically as backups for growing distributed generation systems. For this to happen, disruptive technologies such as solar energy, battery storage, hydrogen energy storage, robots and automation will need to continue to evolve and become increasingly competitive $[77,78]$. Furthermore, a great challenge for the sector is that these disruptive technologies are expected to make traditional assets obsolete in economic terms. There is a concern expressed by the executives about the level of investment and the high risks private companies may encounter, knowing that there are no clearly identifiable actors to bear these risks.

New technologies are also shifting organizations to new business models. Traditional cultures in electric utility companies are facing this change, especially due to the increase in the use of renewable energies and distributed generation. An industry that for over a century has made only minor changes in its business model now is aware that it will need to draw nearer to models similar to those found in technology companies, which may become new players in the sector (Amazon, Google, Apple, etc.). These tech companies have a competitive advantage on the use of data and their intimate knowledge of their clients, an asset that the electric sector companies do not have. Therefore, digitalization and innovation in the sector is a necessity for an approach to attract and retain customers, which will guarantee a closer relationship. Here are where technological advances with big data, blockchain, artificial intelligence and deep learning are becoming more widely studied and applied in the electric utility sector.

The IEEE Global Initiative on Ethics of Autonomous and Intelligent Systems [79] details how the involvement of "several hundred participants", from the scientific community, worked on the development of autonomous and intelligent systems, reflected on ethical principles, gave recommendations and identified issues that may impact society with new technologies. Among the various issues considered in the report, three are relevant for this discussion of the concern about the technological transition in the work environment and the inevitable replacement of humans by autonomous intelligent systems: 1 . the protection of worker rights and their psychological and mental well-being; 2 . the altered workplace relationships and the nature of work; 3 . government policy adaptation and societal change that holds out future prospects with expectations for education and training. Solid ethical cultures in the sector should be well equipped to address these issues and be already aware of toxic cultures that have been encountered in tech companies and other sectors e.g., abuse of a dominant position (anti-competitive), data privacy issues and harassment in the workplace.

\subsubsection{Legal Setting}

The terms "high level of judicialization" and "judicial (in)security" appeared often in the interviews in reference to an uncertain and unstable regulatory system. Interviewees emphasized that the electric sector like any other sector needs a stable and safe regulatory system for consumers and investors. With this, consumers will receive energy at a fairer and lower cost and investors need this stability to be willing to invest. Development in the sector may also be stalled with high tax rates on energy, making products and new technologies more expensive for the end user. The electric sector in South America, for example, has promoted public hearings to discuss reforms of the sector, with regards to transmission, generation, and distribution. The purpose of hearings is to steer towards a more open and modern legislation that will facilitate the development of distributed generation and lower the cost of renewable energy technologies. A stable legal framework would confront future challenges to obtain the right investments needed for a clean energy transition. Technology is understood to be the actual driving force for this transition.

The barriers encountered to an energy transition have a complex relationship with the development of regulatory frameworks. Laws and regulations are perceived by the 
executives to be outdated and have not kept a pace of technological advances. The regulatory framework influences the ways in which the sector evolves and counterintuitively can advantage options that are neither cost effective nor in the interest of companies, consumers or society. Executives are troubled in relation to the financial and economic sustainability of the electric sector because it depends on meaningful changes in the regulatory framework. These needed regulatory changes are difficult to achieve and then to implement as they depend first on political will and then on regulators' activities. The World Energy Outlook 2018 report [80] introduces three possible future scenarios for the energy sector: Current Policies Scenario, New Policies Scenario and Sustainable Development Scenario. There is considerable emphasis on the development and choices among policies that will affect the energy system in the future. In the New Policies Scenario, for example, policies "play a critical role, notably those relating to energy efficiency, renewable resources, measures to curb air pollution and the phasing-out of fossil fuel subsidies" [80] (p. 38). Regulatory barriers, that are consistent with existing policies, are discussed in the Current Policies scenario. The scenario depicts the rise of fossil fuels and "leaves only a small amount of headroom for renewables" [80] (p. 38). There is uncertainty with respect to the demand for electricity that is predicted to increase in the future as "governments are pushing to achieve full electrification by 2030" [80] (p. 386).

According to interviewees at $\mathrm{EUMb}$, legal and the regulatory systems influence the way companies in the electric sector relate to and communicate with the market i.e., positioning of the brand and the necessary competencies, skills and ethical awareness of employees. Changes in regulation may result in a more restricted or more open market, however, the latter is a current trend engendering a shift in business models and culture. A more open market and the ability to sell energy to end users that are more diverse offers the possibility of diversifying the brand and the workforce. Executives appeared to intuitively perceive that these changes might transform the way companies deal with new time frames i.e., short term contracts for end consumers versus long term contracts for large industries. They fear, however, that short termism may disseminate or exacerbate a culture of instant achievement and profit tallying within the company.

\subsubsection{Economic Setting}

Although, since the pre-industrial era, growth in economic activity is one of the underlying factors for the increase in greenhouse gas emissions it is also the key factor which drives and ensures the development of clean energy technologies and climate change adaptation [64]. Economic diversification and more equitable distribution of wealth would encourage the stability needed by the electric sector, which works primarily with mid to long-term planning horizons. This planning depends on financial stability and sustainability. Without this stability, the sector faces an uncertain environment for shortterm demand.

The market needs incentives for the sector to respond to adaptation and mitigation options such as "innovation and investment in environmentally sound technologies" [64] (p. 26). Interviewees commented on the inertia of the energy sector to reduce carbon emissions, which the IPCC considers to be constraints to adaptation and mitigation options for the reduction of climate-related risks. Markets cannot be designed for an outdated logic still based on the production of energy with coal and gas. There is a need for other types of markets designed and regulated by government, which would provide better economic incentives for decarbonization. For example, subsidies have been granted to increase renewable energy technologies and to reduce greenhouse gas emissions. However, some interviewees discussed the possibility of society rejecting the logic of subsidizing renewables, primarily due to the prevalence of low-cost renewable energy technology already in the grid. In Brazil, lawmakers have debated new regulations on subsidies for distributed generation, which ultimately tax the 'poor' for the introduction of photovoltaic panels. This is a technology not used by low-income populations [81]. Companies in the electric sector, which value an equitable and fair transition for all levels of society, 
should continue to engage and disseminate knowledge to stakeholders on the role that subsidies played in the process of promoting renewable energy and the consequences of continuing with them today i.e., a debate on who benefits and who is negatively affected by the subsidies.

\subsection{Business Idea-Corporate Survival and Development}

From the collected evidence at EUMa and EUMb, this section attempts to articulate a unified 'Business Idea' for both electric utilities. Here we propose a unified business idea for EUMa and EUMb due to the fact that both organizations have various common grounds when it comes to van der Heijden's definition regarding the organization's mental model. These private utilities are similar companies operating in similar value chains; with similar historical backgrounds, as discussed in the History subsection; and similar future ambitions for their businesses i.e., relationship with consumers, renewable energy generation, relationship with society, organizational structure, new market/players etc. From the interviews and field research we were able to intersect these similarities and articulate the business idea in Figure 2. Van der Heijden [44] explains that the "Business Idea is the organization's mental model of the forces behind its current and future success" (p. 63). Additionally, the author introduces this concept for scenario planning in order to make "explicit those aspects of the organization that are crucially tied up with the question of survival and development" (p. xxiii). Through the lens of organizational ethical culture and aligning future scenarios with the articulated Business Idea, organizations are able to conduct an ethical reinterpretation of corporate strategies and policies i.e., reviewing and wind-tunneling their strategies for sustainability in future scenarios.

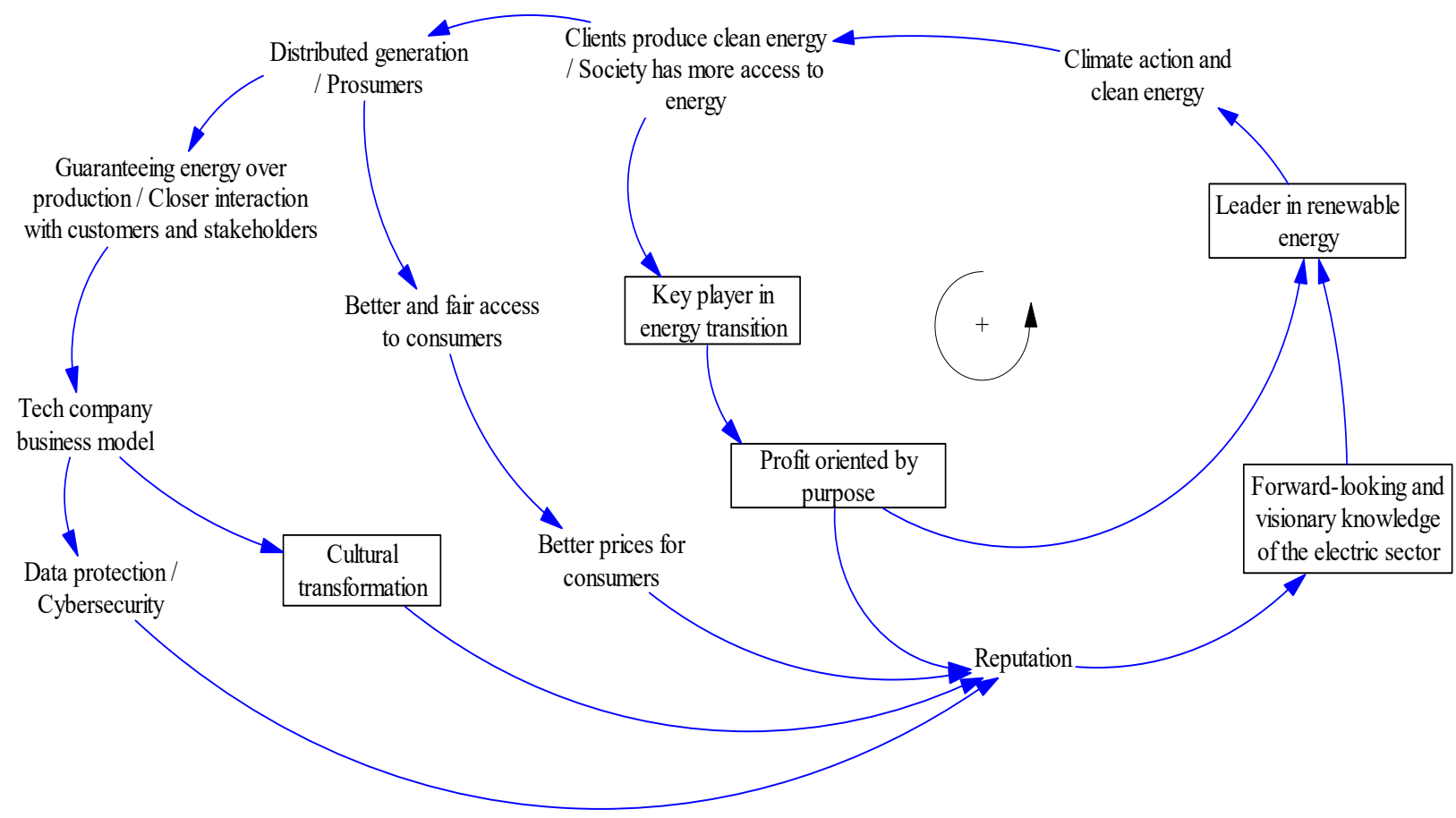

Figure 2. Articulated Business Idea from two private electric utility multinationals (EUMa and EUMb).

The introduction of the business idea to the framework of this article has the objective to articulate, with a positive feedback loop, a combined mental model of EUMa and EUMb in terms of current positioning, social needs and business opportunities, which would lead to new business models, entry into new markets and distinctive competencies. With the articulated business idea in Figure 2, it is possible to visualize the interviewees' strategic priorities and their conception of business model transitions towards climate action by developing clean energy sources, improving technologies for distributed generation and 
empowering consumers to become prosumers. This transition to prosumers provided insights into the capacity of the organizations to prioritize their roles as guarantors of energy over their roles as producers. A closer interaction with the customers and stakeholders had already begun to revolutionize the commercial divisions of electric sector companies. Not only in the electric sector but also in other sectors e.g., finance with fintechs, the tech business model was seen as the most coherent form for transition to secure future success and what is believed to contemplate the needs of consumers. As explained in the technological setting of the PESTLE analysis, major tech companies (Amazon, Google, Apple, Facebook) are expected to be new players in the electric sector and already have the competitive advantage of data storage capabilities and intimate knowledge of their clients. This would give tech companies the advantage in guaranteeing energy for clients. The tech business model consequently would entail a cultural transformation in electric sector companies and the need for them to support advanced data protection regulations and invest in improved cybersecurity mechanisms.

The positive feedback loop (Figure 2) leads to the attention electric companies pay to obtaining and maintaining a good reputation, consistent with their organizational codes of ethics and through their actions. However, reputation should not be the only aspect to consider. More importantly, organizational legitimacy is scrutinized for the achievement of social acceptance. The analysis and scrutiny of reputation, on the other hand, tends to be limited to comparisons among organizations $[82,83]$.

The terms that appear in rectangles in Figure 2 are the distinctive competencies, which according to van der Heijden [44] "must belong to the firm as an institution, and not exclusively to its members individually" (p. 68). For example, the capacity of EUMa having achieved a successful cultural transformation, in the past, demonstrates a distinctiveness that other organizations emulate with difficulty considering the "depth and complexity" of organizational culture [84]. For this recognized achievement in change-management encountered by leadership in organizations, recent research has focused on proposing assessments to minimize the risk of "failed change" and necessary interventions to accomplish successful organizational change [85].

\subsection{Cultural System}

The cultural system for this analysis considers but does not emphasize the publicized definitions of culture that EUMa and EUMb share publicly on their websites and in their reports as values and norms. This is first to ensure anonymity of the organizations and second to avoid bias. The objective here is primarily to make explicit through the interviews, at EUMa and EUMb, and with the ethnographic research conducted during residencies at EUMa, what the interviewees' underlying assumptions and beliefs are that reveal mental models of their cultural systems. Table 4 introduces some of the pertinent characteristics of this cultural system and the following explanation gives an overview of what these characteristics mean for EUMa and EUMb. However, this is a partial observation from interviewees and may not provide a global understanding of the cultural system of these two multinational organizations.

Table 4. Cultural System: pertinent characteristics.

Risk aversion

Market-oriented versus Engineering-oriented

Axiological and Deontological

Subcultures

Zero tolerance for ethical mal practices and violations

Promotes Inclusiveness

Ethics beyond compliance
Shared Knowledge

Innovation

Forward-thinking

Uncertainty avoidance

Organizational Learning

Corporate University

Generates trust

Reputational concern 


\section{Pertinent Characteristics}

Risk aversion: Organizations in the electric sector have developed a culture of risk aversion or a culture which attempts to protect itself by minimizing risk. That is, each step to be taken is carefully calculated and planned before any decision is made. There is a general assumption expressed by the executives that the organizations in the sector will eventually shift towards a fluid organizational structure with more agile governance focused on innovation and influenced by the business models of big technology companies. With this new business model, more risks would have to be taken in certain situations and would need to be trialed in test hubs or directly in the production process. A risk aversion culture was believed to be overly cautious, with meticulous planning before execution and strict adherence to engineering principles that are to guarantee safety. This was coupled with a reputational concern and compliance with standards of due diligence.

Hofstede [86] explains that "uncertainty avoidance does not equal risk avoidance" (p. 148) and that risk is expressed in terms of probability, while uncertainty cannot be given a probable weight. Although the characteristic here is risk aversion and not risk avoidance, there is still a tendency to equate uncertainty avoidance with risk aversion. Nevertheless, with Hofstede's distinction between risk and uncertainty, uncertainty avoidance pertains to EUMa and $\mathrm{EUMb}$ confronting ambiguity and valuing logical structure, clear interpretation and predictability [86]. The relationship of these two characteristics is considered "not equal", but to be interpreted in terms of causality.

Market-oriented versus Engineering-oriented: Within this line of reasoning, and from our research at EUMa and EUMb, we encounter an organizational tendency towards market orientation overshadowing the representative engineering orientation with detailed analysis and long-term planning encountered in electric utility companies. The pressure for financial results, may result in management easily neglecting risk, with short-term myopic decision-making processes and, thus, prioritize immediate financial return over quality service. There is an underlying assumption and belief from interviewees that a transition from a market oriented business model will eventually need to transition back to an engineering oriented business model in order to guarantee long-term safety and quality of services for clients and employees. From a cultural perspective, the market orientation may clash with a proposed forward thinking embodiment of the organization in terms of financial responsibility and strategic priorities for sustainability and long-term climate action. Market orientation for this study is presumed and to be understood to connote financial and results driven. This is a reference to the market power of organizations, increasing productivity and disregarding internal fairness and external social welfare [3].

Axiological and deontological: "Axiological ethic is an ethic of value. It pays attention to a person's first-order preferences or values. While deontologies are generally retrospective in that they call to mind existing precedent, expectations, rules and norms" [87] (p. 312). Both in South America and in Europe EUMa and EUMb manifest a clear normative ethical perspective regarding the actions taken by the electric utilities. That is, a deontological conception where the rules are followed and played by the book, which may concur to zero tolerance for ethical mal practices and violations. Business ethics is ultimately connected to compliance, however, EUMa and EUMb have disseminated through their cultural system that ethics beyond compliance is an indispensable characteristic to consider when evaluating actions and decision-making processes and also where axiology fits well for an environmental ethic anent universal care and the development of relationships for cooperation [87] e.g., towards a fair energy transition.

Subcultures: Multinational companies have a variety of business units, which develop a number of subcultures. This is due to the particularity of each business unit, the specialization of the employees of a specific unit, their ultimate responsibilities within that unit, employee tenure and geographical contexts. Mergers and Acquisitions (M \& As) also markedly affect the creation of subcultures which makes integration of corporate core values ever more challenging. Values remind us of the axiological approach to generate relationships, cooperation and shared knowledge in order to disseminate these core values 
throughout organizations, despite the particularities of distinct business units. In order to avoid subculture silos, EUMa and EUMb have promoted processes to facilitate shared knowledge practices to disseminate core values of their organizations. Consequently, shared knowledge builds innovation capacity within and among subcultures and generates organizational learning networks by which to generate trust among all corporate levels.

Promoting inclusiveness: Inclusiveness was portrayed to be at the forefront of the interviewees' minds, which highlights the importance of diversity to the development of an ethical culture. Promotion of inclusiveness is a task that some organizations have been willing to ensure with diversity (gender, race, nationalities and sexual orientation) non-discrimination and a plurality of worldviews. A corporate university, which at EUMa has an important role in developing the organization's culture, can provide training on inclusiveness and elicit the consciousness of employees to respect and accept diversity in the workplace.

\subsection{Socio-Structural System}

The socio-structural system presents the pertinent characteristics of EUMa and EUMb (see Appendix B, Table A2). These characteristics are specifically associated with the structures, strategies, processes and policies that these organizations put into practice to build their organizational ethical cultures. In Table A2, each characteristic is given a short definition and notes its relationship to the organization's ethical culture. A more detailed analysis of EUMa's socio-structural system is provided in the following sub-section as the result of two residency periods at the organization's headquarters in Europe and a seminar presentation by an executive of EUMa at an ethics forum. This depiction gives an overview and provides some insights for the socio-structural system table, which finally includes inputs for both electric utility multinationals.

\section{EUMa's Socio-Structural Overview}

Ethical risks: For EUMa, within the purview of ethical performance is the impact on reputation. Ethics is observed not to be managed but analyzed through results and performance e.g., benchmarking ethical performance with an external or internal ethics assessment. EUMa's ethics office believes that the risks that are of most concern to the organization are ethical failings that lead to malpractices. EUMa develops an ethical risk matrix to validate and assess the taxonomy of ethical risks and the degree to which they could lead to malpractices. These risks are categorized under management competencies, e.g., finance, information technology, regulation, procurement etc., and management levels, e.g., administrative, managerial, suppliers, clients etc. Furthermore, leadership is considered essential to the minimization of risks and to maintaining a solid organizational culture and high levels of ethical awareness. Workshops for senior management on ethical risk were participatory processes to develop tone at the top and had as their ultimate purpose to mitigate and avoid future ethical risks. Other methodologies have been used to identify risk and internal outputs, such as the Committee of Sponsoring Organizations (COSO) framework. The purpose of applying different methodologies for risk management is to provide transversal integration and to stimulate discussions between departments, committees, stakeholders and geographies.

Although EUMa is a major player in Europe, worldwide it may be considered a "medium" transnational corporation, which allows it greater capacity and flexibility for readjustment and strategizing for the future. In order to build a business ethics management system three objectives are considered by EUMa. First, ensure high levels of ethical awareness. Second, minimize ethical malpractices. Third, maintain a culture through trust, values and transparency.

Ombudsperson/Ethics Officer: Following the signing of the Sarbanes-Oxley Act in 2002, multinational companies that were listed on the United States stock exchange needed to comply with a set of regulations for financial transparency. This obliged EUMa to create a channel for the reporting of malpractices. This also led to the development of their first 
code of ethics and the organization of an ethics committee. Subsequently, EUMa appointed an Ombudsperson, by whom complaints could be received anonymously. Specifically at EUMa, the ombudsperson and the ethics officer are two distinct figures within the organization, however, there is an exchange of information between the departments. The obligations vis-à-vis ethics within the company require different approaches. For example, the ethics officer will have a greater focus on sustainability.

Following the years after the development of EUMa's code of ethics, the organization found within workshops and ethics training tools the means to strengthen their ethical culture, generate trust and disseminate know-how.

Some examples are:

- $\quad$ Tone at the Top;

- Evaluation and management of competencies for collaborators and managers;

- Online Training;

- Story-telling with short films and questionnaires for employees to elicit ethical reflections;

- Partnership with universities and ethics forums;

- Training their suppliers, as the company is aware that within the supply chain ethical malpractice may appear.

Zaal, Jeurissen and Groenland [21] studied the impact that distinct ethical culture dimensions [23] in the financial sector have on unethical behavior towards customers. Regarding the dimensions of 'supportability' and 'feasibility', the authors found that organizations, which are structurally organized to allocate "time, resources and information" to train employees about ethical conduct, responsibility, and norms, will demonstrate "less perceived frequency of unethical behavior towards customers" (p. 839). The ombudsperson, with the support of a department, provides strategic options, procedures and processes to organize this organizational structure for the company and for the employees to "identify and endorse norms and rules", and for employees to "experience trust and respect in their working environment" (p. 839).

Measuring Ethics: EUMa has relied on benchmarking to assess its ethical culture. One of the institutions that measure ethical performance for EUMa applies a more complianceoriented measurement of ethics. Internally, EUMa has created its own ethics assessment tool, which was elaborated through a partnership with a local university. This creates some controversy about whether ethics can be measured or not. However, there are some questions that elicit its functionality for the organization concerning-communication of ethical performance internally and externally; capacity to evaluate incidents, mal practices and risks; and the management of the company's reputation. Other tools for measurement include evaluation from raters, evaluation through marketing, and exit interviews.

\subsection{Six Key Themes Complex System}

Each of the six key themes here presented has been discussed in prior research [6]. This section also derives from an analysis, which revealed the top terms identified with the support of the framework (see Table 5). These top terms were clustered into six key themes [13]. This section complements prior research conducted by the authors of this article and introduces systems maps as sense-making tools towards emerging future systems. The first systems map created (see Appendix C, Figure A1), was developed with NVivo, a qualitative analysis software, and refers to the questionnaires used with executives during a second round of interviews in South America at EUMa and EUMb. It reveals the relationships among the themes through the 'child' nodes, which are the topics of questions posed to the executives within a specific theme. As explained in the Framework and Method section, the executives were each given a theme to reflect upon, according to their expertise and departmental responsibilities. Some executives had knowledge about different themes, and therefore, questions were exchanged and transferred. Another condition for questions to be transferred from one theme to another pertained to the importance of the theme for the topic of corporate culture, as it can be 
noted with the theme From profit to purpose, which was demonstrated to have relationships with all of the themes (16 relationships in total). This might be interpreted as a bias on the part of the researchers to impose the universality of one theme and its influence over other themes during the interviews. However, interviewees, when asked to provide input on the relevancy of the themes for the ethical culture of the organization and to identify potential interconnections among themes, consistently attributed a higher level of importance to the themes From profit to Purpose and Environment and Sustainability. Thus, interviewees underscored the transversal influences of these two themes on all other themes for the development of an ethical culture.

Table 5. Top terms for each cluster.

\begin{tabular}{ll}
\hline Six Key Themes-Clusters & \multicolumn{1}{c}{ Top Terms from Interviews } \\
\hline & Client autonomy, Better prices for consumers, Climate action, \\
& Data privacy and protection, Consumers want greener products, \\
& The focus on guaranteeing energy over production, Transitioning \\
& to an ecosystem of smaller companies, Market orientation versus \\
From profit to purpose & engineering orientation, $\sim 10 \%$ of world population without \\
& access to electricity, Society rejecting the logic of subsidizing \\
& renewables, A business model focused on quality services rather \\
& than solely on return on assets, Future business models \\
& surrounding energy storage, Distributed generation \\
\hline
\end{tabular}

From job for life to entrepreneurship, New generations inspired

Cultural consistency by tech culture, Mergers and acquisitions, The importance of subcultures, Culture building rather than imposing, Transitioning to an ecosystem of smaller companies, Importance of core values

Tone from the top, Retirement of senior executives and the need for generational renewal, Less hierarchy, New generations

The role of leadership inspired by tech culture, Creating new leadership positions due to novelties of the sector, The necessary competencies for future leaders, Ethical leadership and influence on subordinates

$\mathrm{CO}_{2}$ market and pricing, Coherent political framework, Coherent legal framework, Judicial (in)security, Modernizing legislation for

Regulation and relationship with public institutions the electric sector, Regulating distributed generation, High 'judicialization' of the electric sector, (Un)stable regulatory environment, Favorable regulatory guidelines for decentralization, Outdated regulations as opposed to technological evolution, Lobbying, Lack of political and regulator motivation for change

Distributed generation, From consumers to prosumers, Capacity of energy storage, Use of electric cars, Digital revolution affecting businesses in the electric sector, Robotization, The effect of big data analytics and cryptocurrencies on businesses, Consolidation

Digital and technological advances of renewable energy, Arrive at a business model similar to what tech companies have today, Use of technology to further understand the client's needs, Tech companies as new players, Data privacy and protection, Improving customer relationship and loyalty through digitalization, Influence of blockchain in the electric sector, Impact of AI in the workforce

Water crises, $\mathrm{CO}_{2}$ market and pricing, Climate change, Renewable energy, Necessary adaptive measures to climate

Environment and sustainability change, Environmental impact, Decarbonization, Low carbon economy, Energy sector inertia to change, High dependency on fossil fuels, Sustainable development goals, Limit global temperature increase below 2 degrees Celsius, Stranded assets, Colossal investments for the energy transition 
All six themes supported the building process to arrive at future scenarios. Nevertheless, there was a greater attribution to the level of importance and uncertainty surrounding the themes From profit to purpose and Environment and Sustainability that illustrate business model transitions towards climate action and sustainability. The following systems map (Figure 3) uses all top terms from both these themes and adds specific terms from other themes in order to elaborate the future scenarios. A description of the top terms used for the systems map in Figure 3 are provided in the Glossary (see Appendix A, Table A1). The systems map is supported by literature, by the expertise of the interviewees and especially driven by the purpose of the research which questions systemic change and adaptation of ethical culture. A business model transition towards climate action does not only depend on the will-power of organizations but also on various factors which may facilitate, or not, achieving ethical strategic priorities of the SDGs, as illustrated in three components of the framework (PESTLE, History and Business Idea).

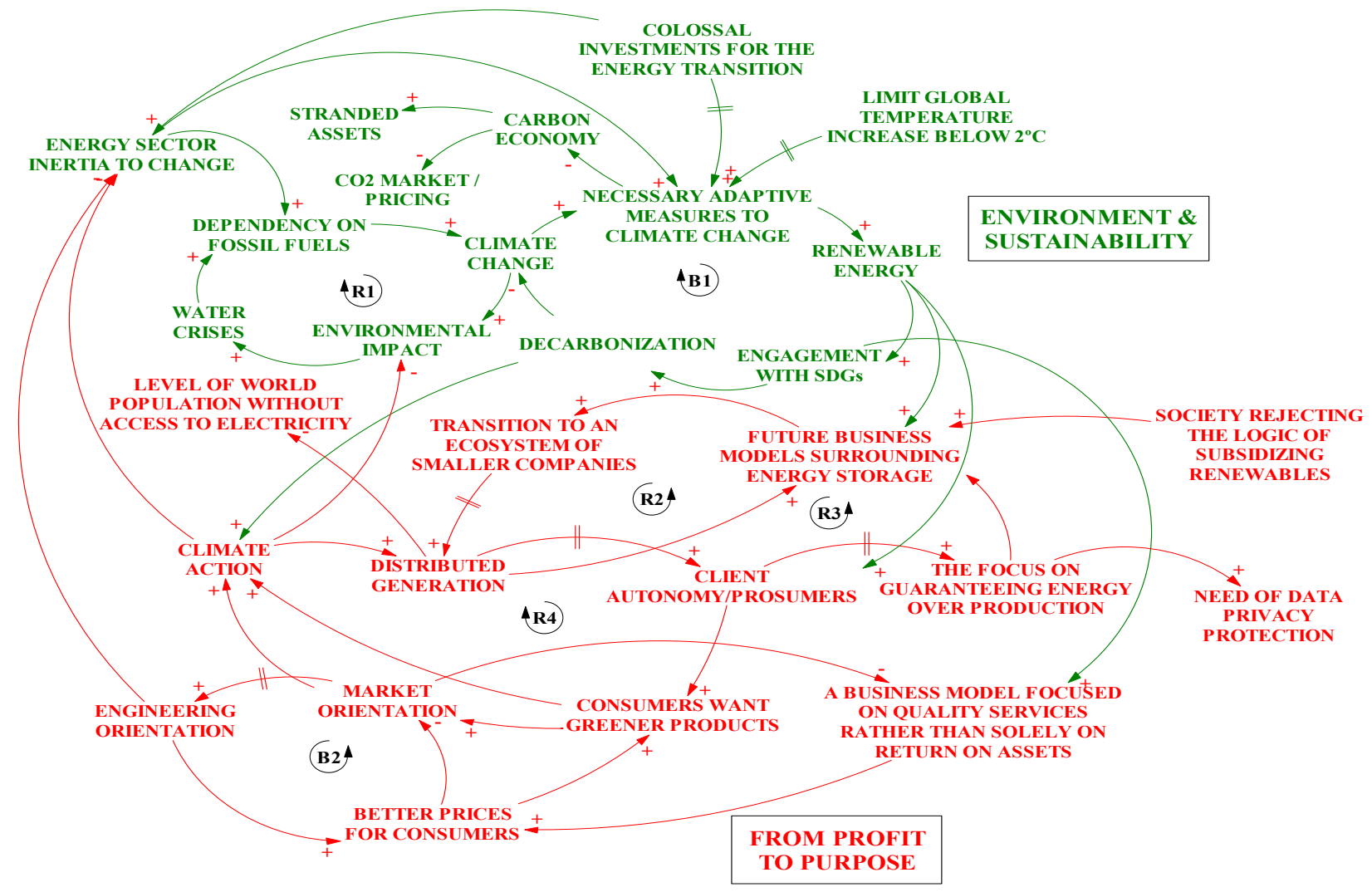

Figure 3. Preliminary causal loop diagram (CLD) of the themes From profit to purpose and Environment and Sustainability.

4.7. Four Scenarios to 2040 on Future Organizational Dynamics and Ethical Culture in the Private Electric Utility Sector

4.7.1. Scenario 1: From Profit to Purpose and Environment and Sustainability-From the Perspective of the Theme the Role of Leadership

A central issue is whether or not organizations can make the transition from what have been dominant profit maximization practices to a fundamental transformation to purpose-oriented practices, which deliver value for all stakeholders, foremost including customers and society.

In 2040, new governance models have dictated the evolution of the value chain of the electric utility sector relative to generation, distribution, transmission and commercialization. The sector has experienced a human capital challenge with the retirement of more than $40 \%$ of the workforce, including management and leaders. The generational renewal process has attempted to align the incoming cohorts with the new profiles and 
their competencies and skills that are greatly different from those of past generations. The new generations are fully digitally literate, more concerned with safety and well-being, and attentive to analytics. Differently from those companies that were prepared for this transition, this endeavor has been a struggle for the companies in the sector that did not prepare their human capital for the necessary new skills that incoming leaders need. This scenario proposes that many companies have adapted their corporate governance structures and consequently the Chief Ethics Officer (CEthO) now is either just as highly ranked or above the Chief Executive Officer (CEO). Both sit on the board of directors, where the CEthO is usually vice chair. Although, companies have been highly influenced by tech culture, the ethical leader at the forefront in this scenario guides the business model focused on the quality of services rather than solely on the return on assets. In this future, it is the CEthO who must answer to shareholders and stakeholders in order to ensure that the company is firstly a purpose-oriented business for the collective value. The conceptualization of CEO activism and multinational activism during the 2020s played a major role that uplifted the importance of the CEthO. Other companies, that did not count on a CEthO for top leadership, transitioned with the Chief AI Officer (CAIO) or Chief Technology Officer (CTO), which was to be expected given the escalating dependence on technology in the early 2020s. In these companies, the status quo was maintained and little to no progress was made in terms of business ethics in a digitalized world.

The CEthO is a figure who is able to maintain the ultimate purpose of companies, which is to certify the best interests of society, customers, employees, shareholders and other stakeholders. Profit is the means and not the end in this business model. Furthermore, the $\mathrm{CEthO}$ has the necessary competencies for climate action and progress towards a continued fair energy transition. The leadership of corporations is motivated by all (she, he, they or other gender neutral pronouns) who understand the humanistic importance of being a leader and who rely on ethical frameworks for decision making that goes beyond share value. Alternatively, due to the delay in guaranteeing a higher level of importance to the role of Chief Ethics Officer, the necessary adaptive measures for climate change were stalled, and in 2040 we are still dealing with a dependency on fossil fuels in specific industries. Ultimately, for this reason, the electric sector inertia to change still exists and feeds into a reinforcing feedback loop towards runaway collapse (see R1 in CLD figure).

Present weak signal: CEOs, multinationals, central banks and investors capitalizing on eco-social activism or legitimately concerned therewith, are indicators of how the electric utility companies will need to learn to internalize into their ethical cultures the rising social empowerment of their employees and of society. Growing demands for more just work environments and for a sustainable energy transition will prescribe the competencies of the leader of the future.

4.7.2. Scenario 2: From Profit to Purpose and Environment and Sustainability-From the Perspective of the Theme Regulation and Relationship with Public Institutions

According to the World Energy Outlook [88], in 2019, the electric sector represented $19 \%$ of energy consumption with prediction of an expected increase to $24 \%$ in 2040 . In this scenario, in 2040, electricity has gained importance in the total energy consumption. This was largely accomplished with the electrification of transport, but also through the electrification of other utilities, such as heating (transition from gas/fuel to electric). Therefore, in this future the consumption of electricity increases through electrification. This is a future in which the production of electricity is decarbonized because it was able to achieve a successful renewable transition with the support of regulation. Regulation was able to manage the transition and align correctly the incentives of various agents in order to have the necessary investments for a decarbonized energy transition (see B1 in CLD figure). Nevertheless, regulatory milestones needed to be attained in order to ensure better policies, decarbonize the economy and limit global temperature increase. This required not only the commitment of governments in building political and legal frameworks to favor mechanisms for climate action but also from companies with research and development $(R \& D)$ proposals to energy regulatory bodies and to financial and budget 
governmental entities to modernize the sector and generate a culture of trust, transparency and responsible investing. The corporate relationship and a collaborative development with public institutions needed to evolve with trust building processes during the 2020s and through the 2030s in order to avoid further judicial insecurity and to act as a protagonist in helping to shift the behavior of government for the benefit of society. This transparent and trust building ethical culture of electric utilities, for the well-being of society and the environment, played an important role in securing a climate action agenda independently of political ideology and interests.

The regulatory system, assisted by purpose oriented electric utility companies, guaranteed an open market to help ensure better prices for consumers with renewable energy production and fair access to renewable energy technologies for all levels of society. Electricity is now sold to domestic microgrid end users. This enabled company cultures to understand the diversity of their consumers and consequently diversify their workforce, intensify necessary competencies, and build ethical awareness on how to manage a closer digital relationship with customers. Finally, after a regulatory transition in 2030, Environmental, Social and Governance (ESG) reporting in 2040 has continued to be mandatory in the European Union and companies on the United States stock exchange. Consequently, most electric utility multinationals in South America and around the world need to abide to ESG reporting. This regulation also gave companies the leverage with ESG reporting to disseminate further a foresight culture to report on resilience and future crises assessments for each criterion.

Present weak signal: The signals that arrive from a regulatory perspective are probably the most difficult to detect across all four scenarios. The International Energy Agency has dedicated large-scale reports on future scenarios for the energy sector affected by current policy frameworks and these scenarios are recurrently revised. An up to date regulatory framework for a technology-intensive sector is dependent on a business-regulator productive relationship, as is an up to date regulatory framework for a social-intensive and purpose-oriented sector directed to further energy transition.

4.7.3. Scenario 3: From Profit to Purpose and Environment and Sustainability-From the Perspective of the Theme Digital and Technological Advances

In 2040, new players have established themselves in the electric utility sector. Google, Apple, Amazon, Tesla and Facebook are among the tech companies who are now guaranteeing energy for their clients. The technological evolution was a roadmap of adaptation for the electric utility companies and led to a revolution in the relationship between electric utilities and clients. In this scenario, we are now definitely within a decentralized logic of assets. Society is producing its own energy (primarily with solar panels) which gave an impulse to the corporate-customer relationship. Traditional electric companies transitioned to become various smaller companies, which are the driving forces for decarbonization and complete electrification of mobility and transportation.

Electric utilities and new players that recently joined the sector are closer than ever to their clients and are present inside the clients' homes guaranteeing energy and with a business model to provide solutions based on client data. This is primarily accomplished with Artificial Intelligence (AI) and Machine Learning (ML), which provide information and make operational decisions. In this scenario, where technological autonomy is more prevalent, errors may occur, and after a review of regulations passed in the 2030s the companies will be held responsible for unethical actions that AI may cause, and not the technology itself. In this scenario, the customers in both South American and European countries have the opportunity to freely choose a supplier. The electric utilities had to go through a transformation where they are companies in service to customers. Prediction of their needs has become the skill set and foci of the culture of the organizations in the sector. This organizational cultural transition was one of the main turning points for the companies during the 2020s and 2030s.

In terms of guarantee and solutions, the corporate-customer relationship has become so close that electric utilities are now entering the insurance market, having understood 
that electricity is not the entirety of their business. Many electric utilities that did not adapt to the digital revolution were substituted by tech companies, which over the past decades had the advantage of possessing large quantities of customer data. More so, pressured by regulatory bodies and due to increasing and insurgent cyber-attacks during the 2020s and 2030s, tech companies are also now at a competitive advantage with their cybersecurity mechanisms to certify the privacy and protection of clients' data.

As the culture of technology evolved during the 2020s and 2030s, in the year 2040 we are still learning how to deal with the fast pace of innovation and high-tech advances. Nevertheless, this scenario shows us that companies needed to strengthen a culture of collaboration to avoid the sense of individualism that technology fosters and to comply with the many regulations created to promote civilized online relationships, data privacy protection, cybersecurity and respect for a more diverse corporate environment.

Present weak signal: Towards the end of 2010s and in the beginning of 2020s technology was consolidated as a collaborative and bridging tool, however, it demonstrated capacity to also create divides and explicit opinions and views against minorities, facilitate access to disinformation/misinformation and disseminate online hate which transcends to the political and social realms. We are still learning how to filter and regulate these unethical actions. For this, in the 2020s attention should be given to signs of shifting behaviors that are a result of emerging new technologies and those that will eventually be used in the sector e.g., blockchain and machine learning.

4.7.4. Scenario 4: From Profit to Purpose and Environment and Sustainability-From the Perspective of the Theme Cultural Consistency

In 2040, the shift to an energy tech model has obliged electric utilities to hire employees that have the same competencies or competencies superior to those who work at established tech companies such as Google, Tesla and Amazon. The term job for life has lost its meaning and there is a clear conceptualization of professional liquidity and ephemeral contracts in organizations. Employees are younger and entrepreneurial who after 3 to 4 years at an electric utility will start their own businesses with the support and interest of the electric utility company. Many other employees are hired only for short-term contracts and for specific projects without a clear connection to the company culture.

An electric utility multinational is no longer a company with a well-defined border, it is rather an ecosystem of small companies around the main multinational in a very loose way. During the 2020s and 2030s, M\&As were intensified in order to keep up with innovation and technological evolution, which were at first favorable for the energy transition. Intensified M\&As weakened corporate purpose to benefit collective well-being and provide value for society. This is due to a business model that focused on acquiring emerging businesses in order that traditional electric utility multinationals could monopolize the market and suppress competition from other electric utilities and also from tech companies which are the new players in the sector. A grab and get all culture is the norm. What should have been a reinforcing feedback loop (see R2 in CLD) towards an evolution of distributed generation and widespread production of clean energy turned into a market-oriented model focused primarily on maximizing profit. The large ecosystem of smaller companies surrounding the core electric utility multinational made guaranteeing cultural consistency through the dissemination of core values a near to impossible task, which consequently affected the ethical culture of electric utilities with a persistence of mal practices.

Present weak signal: Multinationals find it difficult to achieve a common ground that will sensitize and educate a conglomeration of business units on issues of environmental and social responsibility. Lack of commitment to core values and diminished appreciation for subcultures may be some of the causes. With a larger ecosystem of subcultures this can accumulate over time and, therefore, the necessary measures to ensure connectivity, purpose, and a sense of belonging need to be implemented and accounted for structurally and methodologically. 


\section{Conclusions and Scenario Implications}

Scenario planning often focuses on mental models. As a rule, these are exceedingly difficult to penetrate, access, approach, modify or change. We are similar to the four blind men in the Indian fable groping the elephant, until we peek out from behind our blindfolds. Conventionally and by necessity businesses and activities in general function based on projections and predictions, so that when asked to consider pure possibilities outside the box, it is difficult for anyone to make that leap, to suspend beliefs.

The participant executives delivered fragments of the past and present as they perceived them to be and extrapolated to possible futures within their individual and collective realms of understanding. This research and their contributions took place for the most part in the years 2017, 2018 and 2019, before the 2020/2021 COVID-19 pandemic and the several catastrophic climate and technological events during this time. These repeatedly pointed to ethical failures and magnified worldwide attention on them and on the responsibilities of industries, governments and leaders. Consequently, these have resulted in the increased engagement of industry leaders in issues of ethics and climate and social responsibility. However, it is evident that the participant executives already had these same concerns before the impacts of 2020/2021. The optimism, pessimism and neutralities of their visions of futures, interestingly, do not contemplate pandemics and their effects on the fabric of society or their own industry.

It is important to highlight that the scenarios here presented express broadly encouraging outcomes. This is a result of the optimistic assumptions shared by most interviewees as to where they believed the sector and their organizations were headed. Although their perceived mental models may have been constrained and limited by encouraging futures, the executives did not disregard challenges and barriers in their roadmaps to the future of their organizations, industry and sector.

As concluding comments for this article, we present an initial discussion of the Sustainable Development Goals (SDGs) that stand out across all four scenarios and how they may be observed as leverage points for specific scenarios. We also review the articulated business idea with respect to the adaptation to new business models and implications of closer business-customer relationships.

\subsection{Scenario Implications and Business Idea Review}

Within an electric utility ethical system, the capacity to implement changes intended to achieve and adapt to a sustainable future depends on the confluence of distinct agencies such as policy-makers, leadership and society. Leaders as decision makers and moral agents in the electric sector need to take into account the flow of power and the tensions within current power structures, which may either impede or drive transformation. In organizations the importance of leadership committing to the 17 SDGs and their 169 targets is fundamental. EUMa and EUMb rely on SDGs [89] to support their corporate strategies for sustainability. Prioritizing some or all of the SDGs in multinationals and their subsidiaries is largely dependent on the type of industry and geographical context, chiefly guided by corporate strategy from headquarters. Increased accountability delegated to multinationals with SDGs at the fore of organizational goals, such as the appointment of a CEthO suggested in Scenario 1, is positive leverage for corporate transformation and reflects the need to understand the contextual realities of the multinational in different geographies. European headquarters, for example, may not always contemplate in their system the social challenges faced in South America. For this, Scenario 1 reminds us of SDG 4 (quality education), SDG 5 (gender equality) and SDG 8 (decent work and economic growth) with respect to incoming cohorts of employees and leaders with new competencies. The generational transition in the labor market and the new competencies of employees require investments to improve education in the host society where the electric utility provides its services. This addresses SDG 10 (reduced inequalities) by providing the new generation access to new knowledge, new jobs and stability to build their careers and become leaders within an ethical framework. Furthermore, rethinking the contexts in 
which an electric utility multinational provides services it should be imperative to consider the economic and social deficiencies of the various countries where they operate. In South America again, SDG 1 (no poverty) and SDG 2 (zero hunger) are far from being met.

Scenario 2, Scenario 3 and Scenario 4 have, as a key feature, the joint commitment between government and private electric utilities aiming to ensure a fair energy transition for customers and stakeholders. Scenario 4 considers this government-business relationship from the perspective of the creation of numerous business units and a lack of cohesion in core values. The key features for these three scenarios approach SDG 17 (partnerships for the goals), with regards to assuring climate action with SDG 13, and a trust building ethical culture in electric utilities to assist in the development of necessary policies that will facilitate innovation with SDG 9 (industry, innovation and infrastructure). They also address necessary commitments to guarantee better prices for consumers through renewable energy with SDG 7 (affordable and clean energy), improve the quality of living in sustainable cities and communities with SDG 11 e.g., electrification of mobility, and guarantee responsible consumption and production of energy with SDG 12.

These three scenarios provide further insight into how the relationship between customers and electric utilities is changing. A closer relationship with clients and consumers and the transition to new business models means that there is room in future planning to reinforce ethical behavior with stakeholders and to understand the many facets of the ethical responsibilities that pertain to this closer business-consumer relationship [90-94]. Furthermore, as exemplified by the articulated business idea in Section 4.3, a transition to new business models is already becoming a strategic concern for companies in the electric sector, which will challenge their current beliefs, values and capacity to accomplish the energy transition [95].

With a review of the articulated business idea, we see that both electric utilities for this research are in agreement about the development of infrastructure, technologies, and policies for renewable energy in favor of an advocated energy transition. This transition and a closer relationship with consumers, in the business idea, aims to provide better prices to consumers as renewable energy has a lower cost to generate and operate. In 2021, for example, we have seen, in countries around the world, record increases in prices due to regulations on $\mathrm{CO}_{2}$ pricing and impact of climate change. We can also consider that this was aggravated by the lack of past public and private commitment to and investment in renewable energy. Additionally, there is the need to include evidence of SDGs as leverage points in an organizational ethical system which stood out across all four scenarios. According to the executives, securing profit, which is only then oriented by purpose, was in their perception the most coherent path forward in order to be able to commit to the energy transition, to guarantee corporate strategies for sustainability and to ensure an ethical positioning in society. This leadership perception tends more to the organizational culture of maximization of corporate earnings, which still prevails and is seen as the only way to fulfill an ultimate goal for collective value. Beyond expectations for the implementation and improvement of policies and of government mobilization, ideally, businesses should embrace the opportunity to anticipate the public sector as protagonists for climate action and to propose to government an ethical analysis on 'climate-mitigation assessments'. Companies should recognize their role as champions of the necessary cultural change across the whole of the 'climate-change community'. Lenzi et al. [96] argue, for example, that "ethicists need to be involved from the outset in developing, modeling and evaluating scenarios for reducing emissions" (p. 304). In a corporate setting with a strong purpose-oriented structure, there could be more investment and capability to train ethicists in "climate mitigation research" and, backed by science, they would better understand the impact of new technologies used in the energy transition. This argument would concur with and further incentivize three distinctive competencies, of EUMa and $\mathrm{EUMb}$, articulated in the business idea (cultural transformation, key player in energy transition and forward-looking and visionary knowledge of the electric sector). On the other hand, ethicists can revise and improve corporate rationality in two other distinctive 
competencies, profit oriented by purpose and leader in renewable energy. The first may be conditioned by recurrent fine-tuning of corporate purpose, and the latter by changing the corporate rationality to consolidate the organization as a reference in renewable energy, rather than striving only to be the leader.

The IPCC's 6th assessment released during the final editing of this article details in an almost 4000-page report the dire consequences of human activity on global warming. With a dedicated summary for policy makers, the report clarifies that the public sector is a key actor and there are urgent policies and adaptive measures that need to be implemented by governments around the world. Clearly, the report should not be overlooked by businesses and especially by the private electric sector, which is a major player in confronting climate change, by reducing carbon emissions and devoting efforts to the production of clean energy with renewable sources.

\subsection{Future Research and Limitations}

From the tenets of pragmatism and systems thinking future research can question the collective goals and functioning of these possible new business models. It is imperative to challenge current assumptions and reframe strategies that although they may exhibit purposeful ambitions for the energy transition, they may still overlook ethical responsibilities when guided primarily by profit. This gives further room for researchers to use scenarios on the future of the electric utility sector and, with this, to review and address the challenges to tackling intergenerational fairness and justice [12,97]. A subject, which has gained momentum in foresight and futures studies, however, with little or no concrete scientific research.

The research for this article was limited to the participation of top executives through dialogue interviews. Scenario planning is a participatory and iterative process. These inclusive dynamics of the methodology attempt to narrow the gap of limitations for when the process arrives at its future outcomes and strategic implementation. Nevertheless, this is infrequently the case with scenario planning. There is a continuous process of revision of scenarios, which is exhaustively required with the added participation of experts and stakeholders, to improve plausibility and relevance of scenarios for a given subject. Chiefly, when confronting organizational ethics, participatory environments for reflection are ideal. However, even when participatory environments are organized, structured and facilitated, they are not always capable of including the "highest levels of accountability" and "democratic values" of all who represent the socio-political ecosystem [98]. Duckett et al. [98] debate the relevance of Habermas' Theory of Communicative Action in an attempt to arrive at 'ideal speech situations' and improved democratic participatory dynamics with scenario planning. Yet still, organizational barriers and cultural particularities may reveal organizational reluctance to engage in an ideal participatory, democratic and inclusive environment to reflect upon ethics $[6,99]$.

Author Contributions: Conceptualization and methodology, R.W.D.B.; software and data curation, R.W.D.B.; validation, R.W.D.B. and P.M.S.; formal analysis, R.W.D.B.; investigation, R.W.D.B.; resources, R.W.D.B. and P.M.S.; writing—original draft preparation, R.W.D.B.; writing—review and editing, R.W.D.B. and P.M.S.; supervision, P.M.S.; project administration, R.W.D.B. and P.M.S.; funding acquisition, P.M.S. All authors have read and agreed to the published version of the manuscript.

Funding: This work was supported in part by the European Horizon's 2020 Research and Innovation Program under the Marie Skłodowska-Curie Grant Agreement No 665959 and in part by several other institutions.

Institutional Review Board Statement: The study was conducted according to the guidelines and respects the Helsinki Declaration of the Council on Human Rights and Biomedicine and UNESCO's Universal Declaration on the Human Genome and Human Rights. This project meets the required ethical standards for research development and meets the laws of each country in which such project was developed and other regulatory standards relevant to the project on ethical issues, according to the ethical requirements for researchers set out in the European Charter for Researchers and the Code of Conduct. 
Informed Consent Statement: Informed consent was obtained from all subjects involved in the study.

Conflicts of Interest: The authors declare no conflict of interest.

\section{Appendix A}

Table A1. Glossary for Causal Loop Diagram (CLD).

\begin{tabular}{|c|c|}
\hline Term & Definition \\
\hline Client autonomy/Prosumers & $\begin{array}{l}\text { Equitable share as more of society produces and manages its } \\
\text { own energy. }\end{array}$ \\
\hline Better prices for consumers & $\begin{array}{l}\text { Fair access to renewable energy systems that will guarantee and } \\
\text { provide better prices for all consumers. }\end{array}$ \\
\hline Climate action & $\begin{array}{l}\text { Business models that align aspirational values to act on climate } \\
\text { change with virtues in order to put those values into practice. }\end{array}$ \\
\hline Data privacy and protection & $\begin{array}{l}\text { Shift in business models which will require greater } \\
\text { consideration of clients' data privacy and protection. }\end{array}$ \\
\hline $\begin{array}{l}\text { Consumers want greener } \\
\text { products }\end{array}$ & $\begin{array}{l}\text { Incentives to facilitate the use of environmentally friendly } \\
\text { products by consumers. }\end{array}$ \\
\hline $\begin{array}{l}\text { The focus on guaranteeing } \\
\text { energy over production }\end{array}$ & $\begin{array}{l}\text { Shift in business services within a reality of prosumers and } \\
\text { distributed generation, which will guarantee energy for } \\
\text { consumers rather than produce energy for consumers. }\end{array}$ \\
\hline $\begin{array}{l}\text { Transitioning to an ecosystem of } \\
\text { smaller companies }\end{array}$ & $\begin{array}{l}\text { Uninterrupted transformation of the electric sector towards a } \\
\text { decentralized energy market. }\end{array}$ \\
\hline Market orientation & $\begin{array}{l}\text { Corporate short-termism and myopic culture with an } \\
\text { over-riding financial perspective. }\end{array}$ \\
\hline Engineering orientation & Corporate long-termism, attentive to detail and risk averse. \\
\hline $\begin{array}{l}\sim 10 \% \text { (Level) of world } \\
\text { population without access to } \\
\text { electricity }\end{array}$ & $\begin{array}{l}\text { Technology, measures, and services available to provide fair } \\
\text { access to electricity. }\end{array}$ \\
\hline $\begin{array}{l}\text { Society rejecting the logic of } \\
\text { subsidizing renewables }\end{array}$ & $\begin{array}{l}\text { Multitude of available technologies for renewable energy, } \\
\text { reduction of costs with renewable energy at a comparative } \\
\text { advantage over fossil fuels. }\end{array}$ \\
\hline $\begin{array}{l}\text { A business model focused on } \\
\text { quality services rather than solely } \\
\text { on return on assets }\end{array}$ & $\begin{array}{l}\text { Shift in business culture (e.g., people-centered, forward } \\
\text { thinking, responsible, inclusive and fair) }\end{array}$ \\
\hline $\begin{array}{l}\text { Future business models } \\
\text { surrounding energy storage }\end{array}$ & $\begin{array}{l}\text { Cultural transformation based on the relationship with } \\
\text { consumers. }\end{array}$ \\
\hline Distributed generation & $\begin{array}{l}\text { Variety of technologies (solar panels, wind turbines) that will } \\
\text { enable the generation of clean energy by clients. }\end{array}$ \\
\hline Water crises & $\begin{array}{l}\text { Droughts and lack of water resources to produce energy. In } \\
\text { regions that have not sufficiently invested in renewable energy } \\
\text { this will lead to the need for using other back-up sources (e.g., } \\
\text { thermal power). }\end{array}$ \\
\hline $\mathrm{CO}_{2}$ market and pricing & $\begin{array}{l}\text { A market with a political and regulatory framework which will } \\
\text { influence decision-making in the electric sector towards social } \\
\text { welfare (e.g., generating electricity with coal being more } \\
\text { expensive than with gas). }\end{array}$ \\
\hline Climate change & $\begin{array}{l}\text { Human influence on the warming of the climate system with } \\
\text { impacts on society and nature. The energy sector is the main } \\
\text { generator of greenhouse gas emissions. }\end{array}$ \\
\hline Renewable energy & $\begin{array}{l}\text { Energy generation from natural resources (e.g., solar energy, } \\
\text { wind energy, hydro energy etc.) }\end{array}$ \\
\hline
\end{tabular}


Table A1. Cont.

\begin{tabular}{|c|c|}
\hline Term & Definition \\
\hline $\begin{array}{l}\text { Necessary adaptive measures to } \\
\text { climate change }\end{array}$ & $\begin{array}{l}\text { Organizational perception of climate change risks and } \\
\text { uncertainties in order to incorporate ethical decision making } \\
\text { processes to reduce emissions, decarbonize, upskill workers, } \\
\text { enable a fair energy transition for workers and communities. }\end{array}$ \\
\hline Environmental impact & $\begin{array}{l}\text { Risks to human and ecological systems (e.g., droughts, sea level } \\
\text { rise, temperature extremes, impacts on biodiversity and } \\
\text { ecosystems, food security, impact on vulnerable and } \\
\text { disadvantaged populations). }\end{array}$ \\
\hline Decarbonization & $\begin{array}{l}\text { Corporate purpose to reduce carbon intensity of electricity } \\
\text { generation. }\end{array}$ \\
\hline Low carbon economy & Efficient energy system less reliant on fuel combustion. \\
\hline Energy sector inertia to change & $\begin{array}{l}\text { Overdependence on fossil fuels, long term and costly investment } \\
\text { in infrastructure for electric power plants or hydrocarbon } \\
\text { exploration. Therefore, large investments in long-term assets } \\
\text { causes inertia to undertake change towards a clean energy } \\
\text { transition. Differently from the electric sector, which refers } \\
\text { specifically to utilities working with hydropower, wind energy, } \\
\text { solar energy, natural gas, nuclear energy and coal power plants, } \\
\text { the energy sector, as a whole, also includes fossil fuels industries. }\end{array}$ \\
\hline Dependency on fossil fuels & $\begin{array}{l}\text { The degree of dependency on fossil fuels (e.g., coal, oil and } \\
\text { natural gas) }\end{array}$ \\
\hline $\begin{array}{l}\text { Sustainable Development } \\
\text { Goals }\end{array}$ & $\begin{array}{l}\text { Cultural shift for corporate engagement and investment to act } \\
\text { and respond to the Sustainable Development Goals. }\end{array}$ \\
\hline $\begin{array}{l}\text { Limit global temperature } \\
\text { increase below } 2 \text { degrees } \\
\text { Celsius }\end{array}$ & $\begin{array}{l}\text { Corporate commitment and promotion of the Paris Accord to } \\
\text { limit global warming below } 2 \text { degrees Celsius. }\end{array}$ \\
\hline Stranded assets & $\begin{array}{l}\text { Current investments for a clean energy transition to reduce } \\
\text { greenhouse gas emissions may be insufficient for the future (e.g., } \\
\text { gas as a bridge fuel for the energy transition and to substitute coal } \\
\text { in the mid-term). }\end{array}$ \\
\hline $\begin{array}{l}\text { Colossal investments for the } \\
\text { energy transition }\end{array}$ & $\begin{array}{l}\text { Mobilization of investment and engagement of pivotal actors to } \\
\text { finance the clean energy transition (private and public). Private } \\
\text { sector moving into new businesses for energy transition. Who } \\
\text { should bear the risk? }\end{array}$ \\
\hline
\end{tabular}

\section{Appendix B}

Table A2. Socio-structural system EUMa and EUMb.

\begin{tabular}{ll}
\hline Pertinent Characteristics & \multicolumn{1}{c}{ Description/Purpose } \\
\hline & $\begin{array}{l}\text { A corporate figure who receives anonymous complaints, manages } \\
\text { ethical complaints, evaluates the ethical performance of the } \\
\text { organization and proposes strategies and projects to consolidate } \\
\text { the organizational ethical culture (e.g., tone at the top and tone at } \\
\text { the middle). The ombudsperson may work side by side with the } \\
\text { compliance department; however, the ombudsperson is not } \\
\text { responsible for compliance related issues. An ombudsperson } \\
\text { leads the Ethics Committee and also participates in other } \\
\text { committees as well. }\end{array}$ \\
Ethics and Compliance Officer & $\begin{array}{l}\text { Usually a corporate figure with legal background who is } \\
\text { responsible for both the legal and ethical branches of the } \\
\text { organization. The responsibilities may overlap with those of the } \\
\text { Ombudsperson such as proposing ethics programs and reviewing } \\
\text { codes of ethics. }\end{array}$ \\
\hline
\end{tabular}


Table A2. Cont.

\begin{tabular}{|c|c|}
\hline Pertinent Characteristics & Description/Purpose \\
\hline Ethics Committee & $\begin{array}{l}\text { Governance, structure and dynamics of an Ethics Committee may } \\
\text { differ across organizations. The Ethics Committee is usually } \\
\text { chaired by a member of the Executive Board of Directors and } \\
\text { supported by a Committee Secretary (Ethics Officer, } \\
\text { Ombudsperson, and Compliance Officer). The committee and its } \\
\text { members analyze ethical incidents, infringements and complaints, } \\
\text { revises internal and external regulations, and assesses corporate } \\
\text { practices and conduct, deferring to the Code of Ethics. The } \\
\text { Environment and Sustainability Committee works closely with } \\
\text { the Ethics Committee and, in some instances, they may be } \\
\text { integrated as one. }\end{array}$ \\
\hline Transversal integration & $\begin{array}{l}\text { An organization has transversal integration when competencies } \\
\text { are transferrable to any given department or business unit. EUMa } \\
\text { and EUMb avoid creating organizational silos with integration } \\
\text { strategies and/or cross-fertilization processes between units. } \\
\text { Beyond competency development, a transversal integration } \\
\text { enables the dissemination of core corporate values and enables } \\
\text { cultural cohesion. }\end{array}$ \\
\hline Hierarchical structure & $\begin{array}{l}\text { The concept of hierarchical structure differs between geographies. } \\
\text { EUMa and EUMb in South America demonstrated a capacity to } \\
\text { adapt well to a more informal hierarchical structure, in which } \\
\text { access to and proximity of leadership is more evident. EUMb in } \\
\text { South America, for example, designed an open space setting for } \\
\text { top executives who traditionally would have had their own } \\
\text { enclosed offices. On the other hand, EUMa in Europe still } \\
\text { struggles to adapt to a more informal setting where hierarchy is } \\
\text { still predominant and evident. This is also influenced by local } \\
\text { geographical culture. }\end{array}$ \\
\hline Exit interviews & $\begin{array}{l}\text { An exit interview or survey is conducted with employees who are } \\
\text { leaving the company. These interviews help characterize if the } \\
\text { employees were satisfied with their professional opportunities, } \\
\text { achievements and relationships in the company. The interviews } \\
\text { also try to identify if employees were respected by colleagues, } \\
\text { pressured to act unethically, or had suffered retaliation. }\end{array}$ \\
\hline Code of Ethics and Conduct & $\begin{array}{l}\text { Codes of ethics and conduct are documents elaborated internally } \\
\text { to guide the companies and its employees to follow moral and } \\
\text { ethical standards. Codes of ethics may also be specific to } \\
\text { professional expertise (e.g., financial officers), management levels } \\
\text { (e.g., middle and top management) and to those external to the } \\
\text { company (e.g., suppliers). Aside from the legal aspects that are } \\
\text { introduced to codes of ethics, companies should also include in } \\
\text { the documents ethical deliberations beyond compliance (e.g., } \\
\text { responsibility, human rights, and fairness). }\end{array}$ \\
\hline $\begin{array}{l}\text { Reputational monitoring and } \\
\text { assessment }\end{array}$ & $\begin{array}{l}\text { Companies deem reputation important to ensure and benchmark } \\
\text { market and social acceptability. EUMa and EUMb monitor their } \\
\text { reputations with regards to their past and current } \\
\text { practices/actions. Additionally, reputational risks are also } \\
\text { assessed in order to avoid negative repercussions for the } \\
\text { companies in the future. }\end{array}$ \\
\hline
\end{tabular}


Table A2. Cont.

\begin{tabular}{|c|c|}
\hline Pertinent Characteristics & Description/Purpose \\
\hline External ethics assessment & $\begin{array}{l}\text { Ethical assessments by external entities provide organizations } \\
\text { certifications and a benchmarking of compliance and ethical } \\
\text { performance, as well as enhancing reputation. }\end{array}$ \\
\hline Internal ethics assessment & $\begin{array}{l}\text { Internal ethical assessments holistically monitor the ethical } \\
\text { performance and practices of companies. Other ethical } \\
\text { assessments may support the ethics office to investigate weak } \\
\text { signals or early warning signs for corporate preparedness. } \\
\text { These signals may be related to a commercial, economic, or } \\
\text { financial event, and may eventually develop into ethical } \\
\text { incidents. }\end{array}$ \\
\hline Management of competencies & $\begin{array}{l}\text { An internal behavioral analysis is applied to manage and } \\
\text { amplify the competencies of employees according to the } \\
\text { evolution of the organization and its future context. As a means } \\
\text { to improve the professional development of employees and } \\
\text { integrate professional profiles of different geographies, this } \\
\text { process identifies the new necessary competencies of employees } \\
\text { from different levels in the company. }\end{array}$ \\
\hline Sarbanes-Oxley Act of 2002 & $\begin{array}{l}\text { Following the copious ethical and legal misconduct of } \\
\text { multinational corporations (e.g., Enron and WorldCom), the } \\
\text { United States Congress passed the Sarbanes-Oxley Act of } 2002 . \\
\text { The law mandated the regulation of publicly traded companies } \\
\text { on the United States stock exchanges. It regulated corporate } \\
\text { conduct, set auditing standards and conduct and ensured } \\
\text { certification of financial statements from top executives in order } \\
\text { to prevent fraudulent financial reporting [100]. }\end{array}$ \\
\hline $\begin{array}{l}\text { Stakeholder engagement and } \\
\text { management }\end{array}$ & $\begin{array}{l}\text { EUMa and EUMb have set internal structures and standards } \\
\text { (e.g., AA1000 Stakeholder Engagement Standard) to identify, } \\
\text { engage, manage and dialogue with stakeholders. Steps include: } \\
\text { 1. Internal perception by mapping relevant stakeholders and } \\
\text { identification of critical topics for stakeholder engagement; } 2 \text {. } \\
\text { External perception and stakeholder relationship through } \\
\text { diagnostic procedures such as dialogue forums, surveys and } \\
\text { workshops. }\end{array}$ \\
\hline Corporate University & $\begin{array}{l}\text { Corporate universities are strategically important for } \\
\text { organizations to upskill and train employees, raise awareness } \\
\text { and improve organizational learning. As mentioned in the } \\
\text { cultural system section, the corporate university also has an } \\
\text { important role in developing the organizational culture in } \\
\text { EUMa. }\end{array}$ \\
\hline $\begin{array}{l}\text { Strategic planning for } \\
\text { sustainability }\end{array}$ & $\begin{array}{l}\text { Both EUMa and EUMb have outlined strategic priorities for } \\
\text { sustainability. These strategies have been aligned to take action } \\
\text { on some or all Sustainable Development Goals. }\end{array}$ \\
\hline
\end{tabular}




\section{Appendix C}

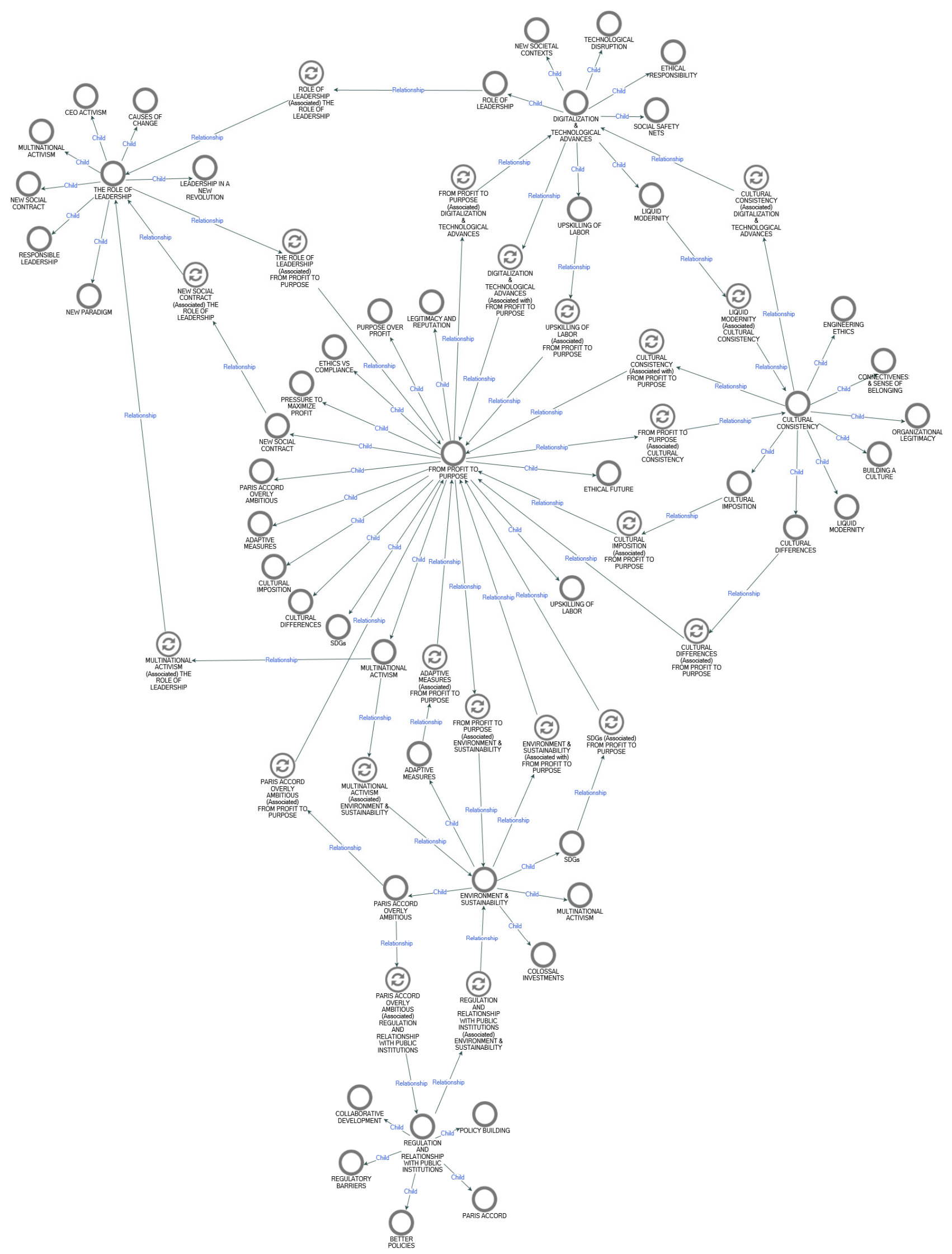

Figure A1. NVivo software systems map of interview questions and themes (relationships). 


\section{References}

1. Birkinshaw, J.; Foss, N.J.; Lindenberg, S.M. Combining Purpose with Profits. MIT Sloan Manag. Rev. 2014, 55, 49-56.

2. Donaldson, T.; Walsh, J.P. Toward a Theory of Business. Res. Organ. Behav. 2015, 35, 181-207.

3. Eeckhout, J. The Profit Paradox, 1st ed.; Princeton University Press: Princeton, NJ, USA, 2021.

4. Freeman, R.E.; Parmar, B.L.; Martin, K. The Power of and: Responsible Business without Trade-Offs; Columbia University Press: New York, NY, USA, 2020.

5. Piketty, T.; Goldhammer, A. Capital in the Twenty-First Century; The Belknap Press of Harvard University Press: Cambridge, MA, USA, 2014.

6. Dal Borgo, R.W.; Sasia, P.M. Toward a Diagnostic Tool for Organizational Ethical Culture with Futures Thinking and Scenario Planning. IEEE Trans. Eng. Manag. 2020, 1-13. [CrossRef]

7. Ramirez, R.; Churchhouse, S.; Palermo, A.; Hoffmann, J. Using Scenario Planning to Reshape Strategy. MIT Sloan Manag. Rev. 2017, 58, 31 .

8. Mayer, D.M. A Review of the Literature on Ethical Climate and Culture. In The Oxford Handbook of Organizational Climate and Culture; Oxford University Press: New York, NY, USA, 2014; pp. 415-440.

9. Schaubroeck, J.; Hannah, S.T.; Avolio, B.J.; Kozlowski, S.; Lord, R.G.; Trevino, L.K.; Dimotakis, N.; Peng, A.C. Embedding Ethical Leadership within and across Organization Levels. Acad. Manag. J. 2012, 55, 1053-1078. [CrossRef]

10. Schein, E.H. Culture: The Missing Concept in Organization Studies. Adm. Sci. Q. 1996, 41, 229. [CrossRef]

11. Ramirez, R.; Mukherjee, M.; Vezzoli, S.; Kramer, A.M. Scenarios as a Scholarly Methodology to Produce "Interesting Research". Futures 2015, 71, 70-87. [CrossRef]

12. Allen, M.R.; Dube, O.P.; Solecki, W.; Aragón-Durand, F.; Cramer, W.; Humphreys, S.; Kainuma, M.; Kala, J.; Mahowald, N.; Mulugetta, Y.; et al. Framing and Context. In Global Warming of $1.5^{\circ} \mathrm{C}$. an IPCC Special Report on the Impacts of Global Warming of 1.5 ${ }^{\circ} \mathrm{C}$ Above Pre-Industrial Levels and Related Global Greenhouse Gas Emission Pathways, in the Context of Strengthening the Global Response to the Threat of Climate Change, Sustainable Development, and Efforts to Eradicate Poverty; IPCC: Geneva, Switzerland, 2018 ; pp. 49-91.

13. Dal Borgo, R.W. Scenario Planning to Assess Ethical Culture. IEEE Eng. Manag. Rev. 2021, 49, 82-91. [CrossRef]

14. Schoemaker, P.J.H.; Day, G.S. How to Make Sense of Weak Signals. MIT Sloan Manag. Rev. 2009, 50, 81.

15. Schein, E.H. Organizational Culture. Am. Psychol. 1990, 45, 109-119. [CrossRef]

16. Sasia, P.M. Pensando éticamente la realidad social. In La Perspectiva Ética; Anonymous; Tecnos: Madrid, Spain, 2018 ; pp. 123-159.

17. Colson, E.; Geertz, C. The Interpretation of Cultures: Selected Essays. Contemp. Sociol. A J. Rev. 1975, 4, 637. [CrossRef]

18. Allaire, Y.; Firsirotu, M.E. Theories of Organizational Culture. Organ. Stud. 1984, 5, 193-226. [CrossRef]

19. Treviño, L.K.; Butterfield, K.D.; McCabe, D.L. The Ethical Context in Organizations: Influences on Employee Attitudes and Behaviors. Bus. Ethic-Q. 1998, 8, 447-476. [CrossRef]

20. Key, S. Organizational Ethical Culture: Real or Imagined? J. Bus. Ethics 1999, 20, 217-225. [CrossRef]

21. Zaal, R.O.S.; Jeurissen, R.J.M.; Groenland, E.A.G. Organizational Architecture, Ethical Culture, and Perceived Unethical Behavior Towards Customers: Evidence from Wholesale Banking. J. Bus. Ethics 2017, 158, 825-848. [CrossRef]

22. Kaptein, M. Integrity Management. Eur. Manag. J. 1999, 17, 625-634. [CrossRef]

23. Kaptein, M. Developing and Testing a Measure for the Ethical Culture of Organizations: The Corporate Ethical Virtues Model. J. Organ. Behav. 2008, 29, 923-947. [CrossRef]

24. Meadows, D.H. Thinking in Systems: A Primer; Chelsea Green: White River Junction, VT, USA, 2008; pp. 1-218.

25. Werhane, P.H. Business Ethics, Organization Ethics, and Systems Ethics for Health Care. In The Blackwell Guide to Business Ethics, 1st ed.; Bowie, N.E., Ed.; Blackwell Publishing: Malden, MA, USA, 2002; pp. 289-312.

26. Vaisey, S. Motivation and Justification: A Dual-Process Model of Culture in Action. Am. J. Sociol. 2009, 114, 1675-1715. [CrossRef]

27. Levin, S. Ecosystems and the Biosphere as Complex Adaptive Systems. Ecosystems 1998, 1, 431-436. [CrossRef]

28. Bertalanffy, L.V. General System Theory; Braziller: New York, NY, USA, 1968; pp. 3-289.

29. Whitchurch, G.G.; Constantine, L.L. Systems Theory. In Sourcebook of Family Theories and Methods: A Contextual Approach; Boss, P.G., Doherty, W.J., LaRossa, R., Schumm, W.R., Steinmetz, S.K., Eds.; Springer: New York, NY, USA, 2009; pp. 325-352.

30. Kast, F.E.; Rosenzweig, J.E. General Systems Theory: Applications for Organization and Management. Acad. Manag. J. 1972, 15, 447-465. [CrossRef]

31. Senge, P.M. The Fifth Discipline; Currency Doubleday: New York, NY, USA, 1994.

32. Sterman, J.D. Business Dynamics; McGraw-Hill: Boston, MA, USA, 2000.

33. Jackson, M.C. Critical Systems Thinking and the Management of Complexity; Wiley: Hoboken, NJ, USA, 2019.

34. Meadows, D.H.; Randers, J.; Meadows, D.L. Limits to Growth: The 30 Year Update; Earthscan: London, UK, 2004.

35. Laszlo, A.; Krippner, S. Chapter 3 Systems Theories: Their Origins, Foundations, and Development. In Systems Theories and A Priori Aspects of Perecption; Elsevier Science \& Technology: Amsterdam, The Netherlands, 1998; Volume 126, pp. 47-74.

36. Ackoff, R.L. Redesigning the Future; Wiley: New York, NY, USA, 1974.

37. Ackoff, R.L.; Emery, F. On Purposeful Systems; Taylor and Francis: New York, NY, USA, 2017.

38. Wolf, S.M. Toward a Systemic Theory of Informed Consent in Managed Care. Houst. Law Rev. 1999, 35, 1631.

39. Werhane, P.H. Moral Imagination and Systems Thinking. J. Bus. Ethics 2002, 38, 33-42. [CrossRef] 
40. Kunsch, P.L.; Theys, M.; Brans, J.P. The Importance of Systems Thinking in Ethical and Sustainable Decision-Making. Cent. Eur. J. Oper. Res. 2007, 15, 253-269. [CrossRef]

41. Bevan, D.J.; Wolfe, R.W.; Werhane, P.H. Systems Thinking and Moral Imagination; Springer International Publishing AG: Cham, Switzerland, 2019.

42. Dewey, J. Logic: The Theory of Inquiry; Holt: New York, NY, USA, 1938.

43. Singer, A.E. Integrating Ethics and Strategy: A Pragmatic Approach. J. Bus. Ethics 2009, 92, 479-491. [CrossRef]

44. Fildes, R.; Van Der Heijden, K. Scenarios: The Art of Strategic Conversation. J. Oper. Res. Soc. 1998, 49, 773. [CrossRef]

45. Ramírez, R.; Wilkinson, A. Strategic Reframing: The Oxford Scenario Planning Approach, 1st ed.; Oxford University Press: Oxford, UK, 2016.

46. Chermack, T.J. Improving Decision-Making with Scenario Planning. Futures 2004, 36, 295-309. [CrossRef]

47. Rohrbeck, R.; Gemünden, H.G. Corporate Foresight: Its Three Roles in Enhancing the Innovation Capacity of a Firm. Technol. Forecast. Soc. Chang. 2011, 78, 231-243. [CrossRef]

48. Van Woensel, L. A Bias Radar for Responsible Policy-Making: Foresight-Based Scientific Advice; Palgrave Macmillan: Cham, Switzerland, 2020.

49. Masini, E.B.; Vasquez, J.M. Scenarios as Seen from a Human and Social Perspective. Technol. Forecast. Soc. Chang. 2000, 65, 49-66. [CrossRef]

50. Bradfield, R.; Wright, G.; Burt, G.; Cairns, G.; Van Der Heijden, K. The Origins and Evolution of Scenario Techniques in Long Range Business Planning. Futures 2005, 37, 795-812. [CrossRef]

51. Wack, P. Scenarios: Uncharted Waters Ahead. Harv. Bus. Rev. 1985, 63, 72.

52. Wack, P. Scenarios: Shooting the Rapids. Harv. Bus. Rev. 1985, 63, 139.

53. Schwartz, P. The Art of the Long View: Planning for the Future in an Uncertain World; Crown Business: New York, NY, USA, 1996.

54. Bredikhin, S. Approaches to Disruptive Change: The Contribution of Complexity Science to Futures Studies. Futures 2020, 124, 102624. [CrossRef]

55. Ramírez, R.; Selsky, J.W. Strategic Planning in Turbulent Environments: A Social Ecology Approach to Scenarios. Long Range Plan. 2016, 49, 90-102. [CrossRef]

56. Bruno, V.; Claessens, S. Corporate Governance and Regulation: Can there be Too Much of a Good Thing? J. Financ. Intermediation 2010, 19, 461-482. [CrossRef]

57. Crooks, E. Business and World Leaders Criticise Trump's Paris Exit. Financial Times. 2 June 2017. Available online: https: / / www.ft.com/content/71a43384-4707-11e7-8d27-59b4dd6296b8 (accessed on 10 March 2021).

58. Bohnen, J. Corporate Political Responsibility How Businesses Can Strengthen Democracy for Mutual Benefit, 1st ed.; Springer: Berlin/Heidelberg, Germany, 2021.

59. Borunda, A. The most Consequential Impact of Trump's Climate Policies? National Geographic 2020. Available online: https: //www.nationalgeographic.com/environment/article/most-consequential-impact-of-trumps-climate-policies-wasted-time (accessed on 8 February 2021).

60. IEA. Global Energy \& CO2 Status Report 2019; IEA: Paris, France, 2019; pp. 3-28.

61. Jones, D. Global Electricity Review 2021: Global Trends; Ember: London, UK, 2021.

62. de Coninck, H.; Revi, A.; Babiker, M.; Bertoldi, P.; Buckeridge, M.; Cartwright, A.; Dong, W.; Ford, J.; Fuss, S.; Hourcade, J.C.; et al. Strengthening and Implementing the Global Response. In Global Warming of $1.5^{\circ} \mathrm{C}$; IPCC—The Intergovernmental Panel on Climate Change: Geneva, Switzerland, 2018; pp. 313-443.

63. IEA. Global Energy Review: CO2 Emissions in 2020; IEA: Paris, France, 2021.

64. IPCC. Climate Change 2014: Synthesis Report; IPCC: Geneva, Switzerland, 2014; pp. 2-151.

65. COMEST. The Ethical Implications of Global Climate Change; COMEST: Paris, France, 2010.

66. COMEST. A Framework of Ethical Principles and Responsibilities for Climate Change Adaptation; COMEST: Paris, France, 2011; pp. 27-28.

67. COMEST. Background for a Framework of Ethical Principles and Responsibilities for Climate Change Adaptation. Int. Soc. Sci. J. 2013, 64, 165-183. [CrossRef]

68. COMEST. Ethical Principles for Climate Change: Adaptation and Mitigation Report of COMEST. Int. Soc. Sci. J. 2014, 65, 93-108. [CrossRef]

69. IEA. SDG7: Data and Projections; IEA: Paris, France, 2020.

70. Ritchie, H.; Roser, M. Access to Energy; 2020, Published online at OurWorldInData.Org. Available online: https: / / ourworldindata. org/energyIEA (accessed on 17 April 2021).

71. IEA. Defining Energy Access: 2020 Methodology; IEA: Paris, France, 2020.

72. Look, W.; Raimi, D.; Roberston, M.; Higdon, J.; Propp, D. Enabling Fairness for Energy Workers and Communities in Transition; Resources for the Future; RFF Resources for the Future: Washington, DC, USA, 2021; pp. 2-55.

73. OECD. The Future of Work: OECD Employment Outlook 2019_Highlights; OECD: Paris, France, 2019.

74. OECD. OECD Employment Outlook 2020; OECD Publishing: Paris, France, 2020.

75. Lauren, A. Robots on the Rise as Americans Experience Record Job Losses Amid Pandemic. The Guardian (London), 27 November 2020.

76. IRENA. Renewable Energy and Jobs: Annual Review 2020; IRENA: Abu Dhabi, UAE, 2020; pp. 3-43. 
77. OECD. A Chain Reaction: Disruptive Innovation in the Electricity Sector; OECD: Paris, France, 2018.

78. IEA. The Future of Hydrogen: Seizing Today's Opportunities; International Energy Agency: Paris, France, 2019 ; pp. 3-199.

79. IEEE Global Initiative on Ethics of Autonomous and Intelligent Systems. Ethically Aligned Design: A Vision for Prioritizing Human Well-Being with Autonomous and Intelligent Systems: Version 2-for Public Discussion; IEEE: London, UK, 2017 ; pp. 2-263.

80. IEA. World Energy Outlook 2018; IEA: Paris, France, 2018; pp. 3-643.

81. Warth, A.; Sabino, M.; Pupo, A. Câmara Discute Entre 'Taxar O Sol' E ‘Taxar Os Pobres'; O Estado de S. Paulo: São Paulo, Brazil. Available online: https:/ / economia.estadao.com.br/noticias/geral,discussao-sobre-paineis-solares-chega-a-camara-e-divideos-parlamentares,70003684331 (accessed on 17 April 2021).

82. Bitektine, A. Toward a Theory of Social Judgments of Organizations: The Case of Legitimacy, Reputation, and Status. Acad. Manag. Rev. 2011, 36, 151-179. [CrossRef]

83. Deephouse, D.L.; Carter, S.M. An Examination of Differences Between Organizational Legitimacy and Organizational Reputation. J. Manag. Stud. 2005, 42, 329-360. [CrossRef]

84. Burke, W.W. Organizational Change. In The Oxford Handbook of Organizational Climate and Culture; Schneider, B., Barbera, K.M., Eds.; Oxford University Press: New York, NY, USA, 2014; pp. 457-483.

85. Stouten, J.; Rousseau, D.M.; De Cremer, D. Successful Organizational Change: Integrating the Management Practice and Scholarly Literatures. Acad. Manag. Ann. 2018, 12, 752-788. [CrossRef]

86. Hofstede, G. Culture's Consequences, 2nd ed.; Sage Publ: Thousand Oaks, CA, USA, 2001.

87. Brady, F.N. A Systematic Approach to Teaching Ethics in Business. J. Bus. Ethics 1999, 19, 309-318. [CrossRef]

88. IEA. World Energy Outlook 2019; OECD Publishing: Paris, France, 2019.

89. United Nations. The Sustainable Development Goals Report 2021; United Nations: New York, NY, USA, 2021 ; pp. $2-64$.

90. Kuokkanen, H.; Sun, W. Companies, Meet Ethical Consumers: Strategic CSR Management to Impact Consumer Choice. J. Bus. Ethics 2019, 166, 403-423. [CrossRef]

91. Chowdhury, R.M.M.I. The Moral Foundations of Consumer Ethics. J. Bus. Ethics 2017, 158, 585-601. [CrossRef]

92. Wells, V.; Ellis, N.; Slack, R.; Moufahim, M. "It's Us, You Know, There's a Feeling of Community": Exploring Notions of Community in a Consumer Co-Operative. J. Bus. Ethics 2019, 158, 617-635. [CrossRef]

93. Lee, H. Understanding Ethical Consumers Through Person/Thing Orientation Approach. J. Bus. Ethics 2017, 158, 637-658. [CrossRef]

94. Roos, D.; Hahn, R. Understanding Collaborative Consumption: An Extension of the Theory of Planned Behavior with Value-Based Personal Norms. J. Bus. Ethics 2017, 158, 679-697. [CrossRef]

95. Kallio, L.; Heiskanen, E.; Apajalahti, E.-L.; Matschoss, K. Farm Power: How a New Business Model Impacts the Energy Transition in Finland. Energy Res. Soc. Sci. 2020, 65, 101484. [CrossRef]

96. Lenzi, D.; Lamb, W.F.; Hilaire, J.; Kowarsch, M.; Minx, J.C. Weigh the Ethics of Plans to Mop Up Carbon Dioxide. Nature 2018, 561, 303-305. [CrossRef] [PubMed]

97. OECD. OECD Public Governance Reviews Governance for Youth, Trust and Intergenerational Justice Fit for all Generations? OECD Publishing: Paris, France, 2020.

98. Duckett, D.; McKee, A.J.; Sutherland, L.-A.; Kyle, C.; Boden, L.A.; Auty, H.; Bessell, P.R.; McKendrick, I.J. Scenario Planning as Communicative Action: Lessons from Participatory Exercises Conducted for the Scottish Livestock Industry. Technol. Forecast. Soc. Chang. 2017, 114, 138-151. [CrossRef]

99. Martínez, C.; Skeet, A.G.; Sasia, P.M. Managing Organizational Ethics: How Ethics Becomes Pervasive within Organizations. Bus. Horizons 2020, 64, 83-92. [CrossRef]

100. Rockness, H.; Rockness, J. Legislated Ethics: From Enron to Sarbanes-Oxley, the Impact on Corporate America. J. Bus. Ethics 2005, 57, 31-54. [CrossRef] 